\title{
Articles
}

\section{On Misreading John Bingham and the}

\section{Fourteenth Amendment}

\author{
Richard L. Aynes ${ }^{\dagger}$
}

\section{CONTENTS}

I. ADAMSON, FAIRMAN, AND THE REPUDIATION OF INCORPORATION $\ldots \ldots \ldots 63$

II. Who Was ConfuSEd? $\ldots \ldots \ldots \ldots \ldots \ldots \ldots \ldots \ldots \ldots \ldots \ldots$

III. How "SingulaA" Were Bingham's VIEws? . . . . . . . . . . . . . . . . . . 74

A. Antislavery Constitutionalism ................. 74

B. Political and Popular Perspectives ............... 78

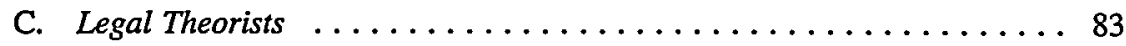

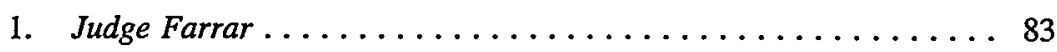

2. Judge Paschal .................... 85

3. Dean Pomeroy ........................ 89

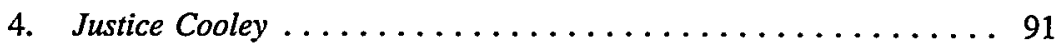

IV. LOCAL CONFLICTS WITH THE BILL OF RIGHTS $\ldots \ldots \ldots \ldots \ldots \ldots \ldots$

$\dagger$ Associate Dean and Professor of Law, University of Akron School of Law. Special acknowledgment is made to Julie Jones, Linda Stiefel, and Linda Stravalaci who, as research assistants through a David L. Brennan Research Fellowship and the University of Akron School of Law Dean's Office, assisted with the research for this article. Akhil R. Amar, Michael Les Benedict, Michael K. Curtis, Paul Finkelman, Harold M. Hyman, Wilson R. Huhn, Hon. Louis F. Oberdorfer, and William D. Rich were kind enough to critique prior drafts of this Article. 
V. INITIAL JUdicial INTERPRETATIONS $\ldots \ldots \ldots \ldots \ldots \ldots \ldots \ldots \ldots$

vi. Conclusion $\ldots \ldots \ldots \ldots \ldots \ldots \ldots \ldots \ldots \ldots \ldots \ldots \ldots \ldots \ldots \ldots \ldots \ldots$

Nearly fifty years ago, Professor Charles Fairman published his seminal article, Does the Fourteenth Amendment Incorporate the Bill of Rights? ${ }^{1}$ According to Fairman, it does not. ${ }^{2}$ Fairman's analysis of the congressional debates and other historical data on the Fourteenth Amendment led him to conclude that the Privileges or Immunities Clause of the Amendment does not make the Bill of Rights applicable to the states. Instead, Fairman argued that the intent of the Amendment's framers is most nearly realized by the use of the Due Process Clause to enforce against the states only those rights "implicit in the concept of ordered liberty." ${ }^{3}$ Fairman reached this conclusion only by dismissing as unreliable numerous statements by Congressman John Bingham, the principal author of Section One of the Fourteenth Amendment. Bingham had repeatedly stated his belief that the Fourteenth Amendment would enforce the Bill of Rights against the states. ${ }^{4}$ Fairman argued that Bingham's position was muddled, inconsistent and idiosyncratic. ${ }^{5}$

Scholars came to view Fairman's work as the "classic" interpretation on this subject and, in the forty-four years since its first publication, his analysis has "shaped much of the constitutional field." Many prominent writers adopted Fairman's interpretation of the incorporation debate, ${ }^{8}$ often sharing his

1. Charles Fairman, Does the Fourteenth Amendment Incorporate the Bill of Rights?, 2 STAN. L. REV. 5 (1949).

2. Id. at 138 .

3. Id. at 139 (quoting Palko v. Connecticut, 302 U.S. 319, 325 (1937)).

4. See Cong. Globe, $42 \mathrm{~d}$ Cong., 1st Sess. app. at 84 (Mar. 31, 1871); Cong. Globe, 39th Cong., $2 \mathrm{~d}$ Sess. 811 (Jan. 28, 1867); CoNG. GloBE, 39th Cong., 1st Sess. 2541-42 (May 10, 1866); Id. at 1291-92 (Mar. 9, 1866); Id. at 1089-90 (Feb. 28, 1866); Id. at 1034 (Feb. 26, 1866).

5. Fairman, supra note 1 , at 25-26. A generation Iater, Fairman reiterated his views on the incorporation controversy in his history of the Supreme Court under Chief Justice Chase. CHARLES FAIRMAN, RECONSTRUCTION AND REUNION, 1864-1888, PART I (1971) [hereinafter FAIRMAN, RECONSTRUCTION I] in 6 HISTORY OF THE SUPREME COURT OF THE UNITED STATES (Paul A. Freund ed., 1971); ChARLEs FairMan, ReCONSTRUCTION AND REUNION, 1864-1888, PART II (1987) [hereinafter FAIRMAN, RECONSTRUCTION II] in 7 HISTORY OF THE SUPREME COURT OF THE UNITED STATES (Paul A. Freund \& Stanley N. Katz eds., 1987). In this later work, Fairman did not offer any significant new information, but bolstered his 1949 analysis by highlighting different state and federal practices and criticizing those who minimized these differences. FAIRMAN, RECONSTRUCTION I, supra, at 1292-93 n.275.

6. William E. Nelson, History and Neutrality in Constitutional Adjudication, 72 VA. L. REv. 1237, 1253 (1986).

7. Harold M. Hyman, Federalism: Legal Fiction and Historical Artifact?, 1987 B.Y.U. L. REV. 905, 924 (1987).

8. See, e.g., RAOUL BERGER, GOVERNMENT BY JUDICIARY 134-56 (1978) (noting author's agreement with Fairman's analysis that Fourteenth Amendment's framers did not intend to apply Bill of Rights against states); Alexander M. Bickel, The Original Understanding and the Segregation Decision, 69 HARV. L. REV. 1, 5 n.13 (1955) ("Professor Fairman demonstrated that the argument [in favor of incorporation] was based on a misreading and an incomplete reading of the original understanding [of the Fourteenth Amendment]."); see also JACOBUS TENBROEK, EQUAL UNDER LAW 214, 345 (1951) (citing Fairman in bibliography and concluding that Bingham's Bill of Rights consisted of Article IV, Section 2; Fifth Amendment Due Process; 
assessment of Bingham's abilities. ${ }^{9}$ Indeed, Fairman's article has been one of the most cited law review articles written since World War $\Pi{ }^{10}$

Still, Fairman has not been without detractors. William Crosskey was, for many years, the most prominent critic of Fairman's work. Crosskey reviewed the same historical record as Fairman, but drew quite different conclusions. He described Bingham as an able person whose theories were "the common faith" of the Republican Party and argued that the historical evidence reveals that the framers of the Fourteenth Amendment intended the Amendment to enforce the Bill of Rights against the states. ${ }^{11}$

Despite Crosskey's analysis and exhaustive research, his critique did little to diminish acceptance of Fairman's work, perhaps because of Crosskey's unconventional ideas in other areas of constitutional law. ${ }^{12}$ For instance, Justice Felix Frankfurter, whose 1947 disagreement with Justice Black in Adamson v. California ${ }^{13}$ prompted Fairman's original project, ${ }^{14}$ never acknowledged Crosskey's criticisms of Fairman. More than a decade after Adamson, Justice Frankfurter remained convinced that Fairman's analysis was correct and described his proof as "conclusive."15 As late as 1968, the exchange between Professors Fairman and Crosskey remained "the only fulldress discussion of [the incorporation debate] in legal periodicals" and was "far

and the right to equal protection).

9. See, e.g., John P. Frank \& Robert F. Munro, The Original Understanding of "Equal Protection of the Laws," 50 CoL.UM. L. REv. 131, 164-65 n.169 (1950) (Bingham had "a strong egocentricity and a touch of the windbag. As a legal thinker he was not in the same class with the top notch minds of his time.").

10. Fred R. Shapiro, The Most-Cited Law Review Articles, 73 CAL. L. REv. 1540, 1550 (1985).

11. William W. Crosskey, Charles Fairman, "Legislative History" and the Constitutional Limitations on State Authority, 22 U. CHI. L. REV. 1 (1954). The exchange began Crosskey and Fairman began the preceding year when Crosskey first criticized Fairman's 1949 article. WILLIAM W. CROSSKEY, POLITICS AND THE CONSTTIUTION IN THE HISTORY OF THE UNITED STATES 1171, 1381 n.11 (1953). Fairman responded with a harshly critical review of Crosskey's book. Fairman's primary purpose was to defend the Supreme Court's reasoning in the pre-Fourteenth Amendment case, Barron v. Baltimore, 32 U.S. (7 Pet.) 243 (1833), and to discredit Crosskey's criticism of it. See Charles Fairman, The Supreme Court and the Constitutional Limitations on State Governmental Authority, 21 U. CHI. L. REV. 40 (1953). Crosskey responded by reiterating his views why Barron had been incorrectly decided and setting forth the reasons why Justice Black had interpreted the Fourteenth Amendment correctly in Adamson v. California, 332 U.S. 46 (1947). Crosskey, supra. Fairman's response reiterated his arguments concerning Barron and his 1949 analysis of the Fourteenth Amendment. Charles Fairman, A Reply to Professor Crosskey, $22 \mathrm{U}$. CHI. L. REv. 144 (1954). Fairman's 1949 article and Crosskey's 1954 article set forth the substantive differences between the two scholars' views on the purpose of the Fourteenth Amendment.

12. Crosskey argued that many of the Supreme Court's most important constitutional decisions were incorrect, that the Constitution was designed to create a strong central government, and that the congressional commerce power was intended to include both interstate and intrastate commerce. See CROSSKEY, supra note 11. For a modern summary of this work, see Paul Finkelman, Book Review: The First American Constitutions: State and Federal, 59 TEx. L. REv. 1141, 1156-73 (1981) and Robert C. Power, Book Review: The Textualist, A Review of the Constitution of 1787: A Commentary, 84 Nw. U. L. REV. 711, 713-16 (1990).

13. 332 U.S. 46, 59-68 (1947) (Frankfurter, J., concurring); 332 U.S. at 68-92 (Black, J., dissenting).

14. See infra note 44 and accompanying text.

15. Bartkus v. Illinois, 359 U.S. 121, 124 (1959). 
more comprehensive than any of the United States Supreme Court cases on this point." 16

A decade later, Raoul Berger published Government by Judiciary. ${ }^{17}$ Although much of Berger's book questioned the legitimacy of the Supreme Court's decisions in Brown v. Board of Education ${ }^{18}$ and Baker v. Carr, ${ }^{19}$ Berger also discussed whether the Fourteenth Amendment should be construed to enforce the Bill of Rights against the states. ${ }^{20}$ Relying on Fairman's analysis as well as his own reading of the original sources, Berger concluded that Bingham was a "muddled" thinker ${ }^{21}$ whose views should be discounted, and agreed with Fairman that the framers of the Fourteenth Amendment did not intend it to enforce the Bill of Rights against the states. ${ }^{22}$ Unlike Fairman, however, Berger rejected even selective incorporation, arguing that the Amendment's framers did not intend that any of the first eight amendments should be made applicable to the states through the Fourteenth Amendment. ${ }^{23}$

In 1980, Michael Kent Curtis responded to Berger's analysis in the first round of what was to become an extended exchange between the two. ${ }^{24}$ Curtis criticized both Fairman's and Berger's scholarship. He found Bingham's constitutional theory understandable, and, like Crosskey, concluded that the Fourteenth Amendment applied the Bill of Rights against the states. ${ }^{25}$

16. Alfred Avins, Incorporation of the Bill of Rights: The Crosskey-Fairman Debates Revisited, 6 HARV. J. ON LEGIS. 1, 3 (1968). Avins concluded that the Fourteenth Amendment's framers intended to apply the first eight amendments of the Constitution to the states. Id. at 25 . Avins independently examined the speeches of congressmen who thought the Bill of Rights applied to the states, and concluded that Crosskey, rather than Fairman, had reached the correct conclusion. Id. at 11. Avins, however, concluded that Bingham's views on Article IV, Section 2 were not widely shared. Id. While this conclusion is mistaken, see infra Part III, Avins correctly identified Bingham's belief that the Fourteenth Amendment enforced the Bill of Rights against the states as the predominant view. Id. at 26.

See also Leonard Levy's introduction to a collection of materials on the incorporation debate coauthored by Fairman, CHARLES FAIRMAN \& STANLEY MORRISON, THE FOURTEENTH AMENDMENT AND THE BILL OF RIGHTS: THE INCORPORATION THEORY, at xiv (1970). While acknowledging some strengths of Fairman's analysis, Levy pointed to several weaknesses. Levy noted that Fairman limited his study of background history to the post-1865 period, provided essentially negative evidence, and interpreted the Amendment's terms literally, ignoring the contextual meaning of the language within abolitionist constitutional theory. Id.

17. BERGER, supra note 8.

18. 347 U.S. 483 (1954).

19. 369 U.S. 186 (1962).

20. BERGER, supra note 8 , at 134-56.

21. Id. at 145 (citation omitted).

22. Id. at 156 n.95.

23. Id. at $115-19$.

24. Michael K. Curtis, The Bill of Rights as a Limitation on State Authority: A Reply to Professor Berger, 16 WAKE FOREST L. REV. 45 (1980). Raoul Berger and Michael Curtis emerged as the two major modern participants in the debate over the application of the Bill of Rights through the Fourteenth Amendment. See Stephen J. Wermiel, Rights in the Modern Era: Applying the Bill of Rights to the States, 1 WM. \& MARY BILL RTS. J. 121, 128 (1992).

Ultimately both Curtis and Berger synthesized their views into books. RAOUL BERGER, THE FouRTEENTH AMENDMENT AND THE BILl OF RightS (1989); MichaEL K. CuRTIS, No State SHALl ABRIDGE (1986).

25. CURTIS, supra note 24, at 215-20. Most recently, Akhil Amar described as "astonishing" Fairman's and Berger's arguments that Bingham "didn't mean what he said" when he invoked the Bill of Rights. Akhil R. Amar, The Bill of Rights and the Fourteenth Amendment, 101 YALE L.J. 1193, 1235 (1992). Amar 
Despite the quality of Curtis' work, his impact on legal scholarship in this area has been limited. ${ }^{26}$ Some scholars have made positive assessments of Bingham's abilities, ${ }^{27}$ but others continue to adhere to Fairman's characterization of Bingham as inept and unintelligible. ${ }^{28}$ Fairman's view-that Bingham was a confused man and that his views provide no guidance when attempting to interpret the Fourteenth Amendment-continues to pervade legal scholarship.

This view and the analysis that supports it are wrong. Building on the work of Crosskey, Curtis, and Alfred Avins, ${ }^{29}$ this Article seeks to strengthen the argument that the Fourteenth Amendment applies the first eight amendments to the states. In particular, this Article focuses on the ideas and influence of John Bingham, the Amendment's principal author. It identifies several sources, some not previously discussed in the literature on this subject, which demonstrate that Bingham intended the Fourteenth Amendment to enforce the Bill of Rights against the states and that many of his contemporaries shared his belief regarding the Amendment's purpose. This Article also argues that Fairman misread critical sources, relied on information taken out of context, ignored important contemporary materials, and buttressed his argument with a flawed legal theory. As a result, this Article argues, Fairman's portrait of John Bingham is distorted and unfaithful to the historical evidence.

Part I of this Article describes the 1947 dispute between Justice Felix Frankfurter and Justice Hugo Black over incorporation and summarizes

argued that Fairman unfairly judged the evidence supporting incorporation. Although Amar did not find support in the historical record for what he termed "mechanical incorporation"-the literal application of the first eight amendments to the states-he nevertheless concluded that, under a doctrine he labelled "refined incorporation," those portions of the first eight amendments that protect personal rights should be enforced against the states. Id. at 1262-68, 1284.

26. For example, two years after the publication of Curtis' No State Shall Abridge, William Nelson, who was familiar with Curtis' work, nevertheless referred to Fairman's 1949 work as a leading article. Nelson, supra note 6, at 1253. Laurence Tribe lists both Fairman's 1949 article and Fairman's 1971 book-but none of Curtis' writings-in the table of authorities of his constitutional law treatise. LAURENCE H. TRIBE, AMERICAN CONSTITUTIONAL LAW 1731 (2d ed. 1988); see also GEOFFREY R. STONE ET AL., Constitutional LAW 1684, 1686 (2d ed. 1991). But see JOHN E. NOWAK \& RONALD D. ROTUNDA, CONSTTUUTIONAL LAW 332 n.3 (4th ed. 1991) (citing both Fairman and Curtis).

27. AlaN G. BOGUE, THE CONGRessman's Civil WAR 34 (1989) (noting that Bingham was "recognized as a man of outstanding abilities"); DAVID DONALD, THE POLITICS OF RECONSTRUCTION, 1863-1867, at 46 (1965) (describing Bingham as the "most thoughtful exponent of the Moderate position in the House"); HOWARD GRAHAM, EVERYMAN's CONSTITUTION 162 (1968) ("Bingham's constitutional theory was more highly developed than that of many of his colleagues" during the 1850's.); STANLEY I. KUTLER, JUDICIAL POWER AND RECONSTRUCTION POLITICS 18 (1968) (describing Bingham as "a prominent and responsible party spokesman on constitutional and legal questions").

28. John Harrison, Reconstructing the Privileges or Immunities Clause, 101 YALE L.J. 1385, 1404 n. 61 (1992) ("Bingham's speeches were highly rhetorical, and his thoughts are hard to follow; he was undoubtedly a gasbag. Whether he was also a gashead is a more difficult and controversial question. My view is that either Bingham's analytical powers were mediocre or he was too lazy to use them."); Raoul Berger, Incorporation of the Bill of Rights: A Response to Michael Zuckert, 26 GA. L. REV. 1, 4 (1991) (quoting with approval negative assessments of Bingham's reasoning abilities).

29. Avins, supra note 16. 
Fairman's subsequent analysis of the purpose of the Fourteenth Amendment with respect to the Bill of Rights. Part II criticizes Fairman's portrait of Bingham as "befuddled" and unreliable, arguing that a comprehensive and fair reading of the historical evidence shows that Bingham consistently espoused a cogent theory about the purpose of the Fourteenth Amendment, and that Fairman, not Bingham, was confused about the Amendment's purpose. Part III refutes Fairman's claim that Bingham's views were "singular," and shows that, contrary to Fairman's assertions, many of Bingham's contemporaries shared his beliefs. Prior to the Civil War, proponents of antislavery constitutionalism supported legal arguments which coincided with elements of Bingham's constitutional theory. Between 1864 and 1871, congressional leaders, jurists, the Ohio Republican Party, the voters of Ohio, and nationally recognized authors of three major legal treatises all endorsed positions consistent with Bingham's constitutional theory. A fourth treatise, cited by Fairman to indicate the "singularity" of Bingham's views, does not, in fact, provide contemporary support for Fairman's argument.

Part IV addresses Fairman's most credible argument. Fairman noted that during the period of the Amendment's ratification, jury practices of many states did not comply with the requirements of the Fifth, Sixth and Seventh Amendments. Fairman argued that had state representatives understood the Fourteenth Amendment to enforce the Bill of Rights against the states, they would not have voted to ratify the Amendment without first discussing the need to change provisions in their own constitutions and statutes that conflicted with the Bill of Rights. Part IV concludes, however, that the conflicts Fairman identified lack the interpretive power he attributed to them because, as Fairman's own examples indicate, many supporters of the Fourteenth Amendment were either unaware of or unconcerned with these conflicts. Part $\mathrm{V}$ documents the consistency between Bingham's views and the earliest federal cases interpreting the Fourteenth Amendment. It demonstrates that subsequent decisions such as the Slaughter-House Cases ${ }^{30}$ and United States v. Cruikshank $^{31}$ repudiate rather than express the intent of the framers of the Fourteenth Amendment.

Part VI concludes that Bingham's views on the Fourteenth Amendment should be credited and Fairman's scholarship on this subject disregarded. This Part sketches the application of Bingham's views to the current constitutional landscape and notes changes in incorporation doctrine that logically follow. Finally, it outlines the challenge to originalist thinkers to determine how the Supreme Court can properly determine which privileges or immunities, beyond the Bill of Rights, the Fourteenth Amendment protects. 


\section{ADAMSON, FAIRMAN, AND THE REPUDIATION OF INCORPORATION}

In Adamson v. California ${ }^{32}$ the Supreme Court considered whether the Fourteenth Amendment barred state constitutional and statutory provisions permitting a prosecutor or the court to comment on a defendant's failure to testify. The Court assumed without deciding that the state laws at issue would infringe on a defendant's Fifth Amendment privilege against self-incrimination "if this were a trial in a court of the United States." ${ }^{33}$ But Justice Stanley F. Reed, writing for the majority, concluded that "[i]t is settled law" that the Fifth Amendment privilege does not protect an individual from state, as opposed to federal, action. ${ }^{34}$

Adamson is best remembered for the dispute between Justices Frankfurter and Black concerning just how "settled" was the law on which the majority relied. Justice Black reviewed "the historical events that culminated in the Fourteenth Amendment" and concluded that the Amendment's framers intended to apply the Bill of Rights to the states. ${ }^{35}$ Justice Black relied primarily on the views of John Bingham and quoted a number of the speeches Bingham had made during the pendency of the Fourteenth Amendment. These speeches indicate that Bingham sought a constitutional amendment to overrule Barron v. Baltimore, ${ }^{36}$ which had held that the Bill of Rights could not be enforced against the states. ${ }^{37}$ Justice Black noted that because Bingham believed that the privileges and immunities of U.S. citizens were "chiefly defined in the first eight amendments to the Constitution of the United

32. 332 U.S. 46 (1947).

33. $I d$. at 50 .

34. Id. at 50-51. Nearly twenty years later, the Court decided that its holding in Adamson had been incorrect. See Griffin v. California, 380 U.S. 609 (1965). While the Court expressly overruled Adamson, it held the Fourteenth Amendment's Due Process Clause, not its Privileges or Immunities Clause, encompassed the Fifth Amendment's protection against self-incrimination.

35. Adamson, 332 U.S. at 71-72 (Black, J., dissenting). Justice Black insisted that the Court had never thoroughly considered the "relevant historical evidence" concerning the intent of the Fourteenth Amendment's framers, and attached to his opinion an appendix summarizing the Amendment's history. Id. at 92-123 app. Accounting for thirty-two pages of the official report of Adamson, this appendix quotes from the congressional debates relevant to the adoption of the Fourteenth Amendment. Twenty-one of these pages contain excerpts from speeches by John Bingham in which he argued for the application of the Bill of Rights to the states through the proposed amendment. Id. at 93, 94-98, 100-02, 103, 107, 111-20 app. Justice Black viewed Bingham's contributions as critical and based much of his position in Adamson on his understanding of Bingham's views. According to Justice Black, "Congressman Bingham may, without extravagance, be called the Madison of the first section of the Fourteenth Amendment." Id. at 73-74.

A half century earlier, Wall Street lawyer William D. Guthrie relied on some of the same legislative history used by Justice Black to conclude that Congress had intended the Fourteenth Amendment to make the Bill of Rights applicable to the states. WILLIAM D. GUTHRIE, LECTURES ON THE FOURTEENTH ARTICLE OF AMENDMENT TO THE CONSTITUTION OF THE UNITED STATES 58-59 (1898). In 1908, Horace Flack evaluated accounts in selected contemporary newspapers regarding the Amendment's purpose and reached the same conclusion as Guthrie. HORACE E. FLACK, THE ADOPTION OF THE FOURTEENTH AMENDMENT 94 (1908). Justice Black cited both Flack and Guthrie with approval. Adamson, 332 U.S. at 72 n.5, 73-74.

36. 32 U.S. (7 Pet.) 243 (1833).

37. Adamson, 332 U.S. at $95-96,100$ app. 
States,"38 Bingham must have meant for the Fourteenth Amendment to enforce the Bill of Rights against the states. ${ }^{39}$

Justice Black found Bingham's speeches compelling evidence that the Fourteenth Amendment framers intended to apply the Bill of Rights against the states. Justice Frankfurter, however, was not convinced. Concurring with the Adamson majority, Justice Frankfurter dismissed statements by Bingham and other legislators and argued that judicial opinions contemporaneous with or just subsequent to ratification more reliably indicated the meaning of the Amendment than "[r]emarks of a particular proponent of the Amendment, no matter how influential." ${ }^{40}$ According to Frankfurter, decisions such as the Slaughter-House Cases ${ }^{41}$ demonstrated conclusively that the Privileges or Immunities Clause of the Fourteenth Amendment did not incorporate the Bill of Rights. These decisions coincided with Frankfurter's view of the Amendment and his understanding of history. He noted that half the states that ratified the Fourteenth Amendment did not require grand juries at the time. Thus, the Justice concluded, the states could not have anticipated that the new Amendment required the practice as one of the privileges or immunities protected from abridgment. ${ }^{42}$ Frankfurter thus "put to one side the Privileges or Immunities Clause," noting "the mischievous uses to which that clause would lend itself if its scope were not confined to that given it by ... the Slaughter-House Cases." ${ }^{43}$

Because Justice Frankfurter did not view statements by the Fourteenth Amendment's framers as useful interpretive tools, he declined to consider directly the evidence cited by Justice Black. Two years after the Court's decision in Adamson, Frankfurter's former student, Charles Fairman, addressed the evidence his mentor had never fully confronted. ${ }^{44}$ In his article, Does the Fourteenth Amendment Incorporate the Bill of Rights?, Fairman directly

38. Id. at 115 app. Justice Black noted that Senator Jacob Howard held similar views. When introducing the Amendment in the Senate, Howard indicated that the privileges and immunities of U.S. citizens included "the personal rights guarantied [sic] and secured by the first eight amendments of the Constitution." Id. at 105 app.

39. Id. at $95,96,100-02$ app.

40. Adamson, 332 U.S. at 64 (Frankfurter, J., concurring).

41. 83 U.S. (16 Wall.) 36 (1872).

42. Adamson, 332 U.S. at 61-62.

43. Id. Having concluded that the Privileges or Immunities Clause of the Fourteenth Amendment did not include the protections of the Bill of Rights, Frankfurter considered the case under the Due Process Clause alone. Id. Relying heavily on precedent, Justice Frankfurter concluded that the Fifth Amendment privilege against self-incrimination was not a fundamental element of due process. As a result, he concluded that the Constitution presented no limitation on the state laws at issue and that the proceedings below did not "offend those canons of decency and faimess which express the notions of justice of English-speaking peoples." Id. at 67.

44. Fairman, supra note 1, at 5. While pursuing his S.J.D. at Harvard Law School, Faiman had been a student in Frankfurter's course on federal jurisdiction. Letter from Annie C. Bombard, Registrar, Harvard Law School, to author (Jan. 19, 1993) (on file with author). In the preface of his biography of Justice Miller, Fairman thanked Frankfurter for his "encouragement and stimulation in the execution" of the writing of the book. Charles FaIRMAN, MR. JUSTICE MILlER AND THE SUPREME COURT 1862-1890, at vi (1939). 
confronted Justice Black's historical evidence, devoting sixty-three pages of his article to the congressional debates leading to the adoption of the Fourteenth Amendment. ${ }^{45}$ Ultimately, he concluded that the debates offered no guidance as to the meaning of the Amendment's Privileges or Immunities Clause because, he argued, no consensus existed among the members of Congress about the meaning of the terms. Fairman wrote, "The debates never established what was to be the basis or measure of the privileges and immunities of citizens of the United States." ${ }^{246}$

In evaluating the evidence cited by Justice Black, Fairman acknowledged that Bingham was a "key figure" whose views were of "great significance" to a study of the meaning of the Fourteenth Amendment. ${ }^{47}$ But unlike Justice Black, Fairman read the historical evidence to indicate that Bingham's views were idiosyncratic, that his statements in Congress were confused, and that his contemporaries did not view him as a logical, careful thinker. In short, Fairman characterized Bingham as "befuddled." 48 According to Fairman, Justice Black's reliance on Bingham's statements was misplaced.

Like Justice Frankfurter, Fairman argued that Congress could not have intended to adopt the Amendment as interpreted by Bingham, because to have done so would have rendered unconstitutional many then-existing state statutes and constitutional provisions. Fairman noted, "The freedom that the states traditionally have exercised to develop their own systems for administering justice, repels any thought that the federal provisions on grand jury, criminal jury, and civil jury were fastened upon them in 1868."${ }^{, 49}$ Three decades after the publication of his 1949 article, Fairman returned to the subject of incorporation and, in a lengthy footnote in his 1971 volume Reconstruction and Reunion, affirmed his prior analysis. ${ }^{50}$ Relying on his earlier reading of

45. Fairman, supra note 1, at 6-68.

46. Id. at 138. Because Fairman concluded that the meaning of the Privileges or Immunities Clause was indeterminate, he argued that the Clause should be interpreted according to the standard articulated under the Due Process Clause. Faiman noted, "Justice Cardozo's gloss on the due process clause-what is 'implicit in the concept of ordered liberty'-comes as close as one can to catching the vague aspirations that were hung upon the privileges and immunities clause." $I d$. at 139 (footnote omitted). Although Fairman never fully explained the basis for this conclusion, it appears that he came to this view because he found numerous examples of the Fourteenth Amendment's framers' intent to protect freedom of speech through the Fourteenth Amendment. Id. If freedom of speech was a privilege or immunity under the Fourteenth Amendment because it was part of the First Amendment, a principled basis would be lacking to explain why only a portion of that Amendment and not others could be enforced against the states. But if the "ordered liberty" formula applied, the Court could enforce that portion of the First Amendment against the states and not necessarily have to enforce other portions of the First Amendment or the provisions of other amendments.

47. Id. at 25 .

48. Id. at 26.

49. Id. at 137 .

50. FAIRMAN, RECONSTRUCTION I, supra note 5, at 1292-93 n. 275. Fairman's 1971 volume sets forth the history of the Supreme Court under Chief Justice Chase. Unlike his 1949 article, the 1971 volume was not directed primarily toward resolving the incorporation dispute. In an early review of Reconstruction and Reunion, I864-1888, Part I, Michael Les Benedict noted that Fairman's "main purpose in these pages is to impart information, not to present conclusions." Michael Les Benedict, Fairman, History of the Supreme 
Bingham's speeches, Fairman wrote that Bingham was "confused"5i and held "peculiar conceptions." 52 According to Fairman, Bingham was "not a man of exact knowledge or clear conceptions or accurate language," "distinguished for elocution but not for hard thinking." 54

In sum, Fairman argued that the Fourteenth Amendment did not apply the Bill of Rights against the states. He reached this conclusion largely because he gave little credence to the views of John Bingham.

\section{WhO WAS CONFUSED?}

According to Fairman, Bingham never clearly articulated what rights he believed were protected by the Privileges and Immunities Clause of Article IV,

Court of the United States: Volume VI, Reconstruction and Reunion, 1864-88, Part One, 39 U. CHI. L. REV. 862, 864 (1972) (book review). Still, Benedict chided Fairman for failing to meet the obligations of the legal historian. He noted, "it should not be the responsibility of the lay reader to pore over the author's assembled data and then draw his own conclusions. He is entitled to know Professor Fairman's opinions as a scholar and to a clear explanation of how the evidence sustains them." Id. at 863-64. Accord Gerald Casper, Review: Charles Fairman, History of the Supreme Court of the United States: Reconstruction and Reunion, 1864-1888, Part One, 73 ColuM. L. REV. 913, 915 (1973) (book review).

The 1971 volume reveals a change in Fairman's perspective with respect to the use of contemporary sources to evaluate the Fourteenth Amendment. In 1949, Fairman placed a high value on present knowledge: "We know so much more about the constitutional law of the Fourteenth Amendment than the men who adopted it." Fairman, supra note 1, at 9. By 1971, however, in evaluating the Slaughter-House Cases, Fairman depreciated "latter-day wisdom," and noted,

it will be rewarding for a while to sweep all this aside, to view the matter simply as it appeared to the participants . . . If [the Justices] show no cognizance of purposes that have since been attributed to the men who carried the Amendment into the Constitution, we should take heed and proceed with caution.

FAIRMAN, RECONSTRUCTION I, supra note 5, at 1343-44.

51. FAIRMAN, RECONSTRUCTION I, supra note 5, at 1288.

52. Id. at 461 .

53. Id. at 462 .

54. FAIRMAN, RECONSTRUCTION II, supra note 5, at 133. This assessment likely reflects Fairman's effort to integrate positive statements about Bingham's abilities by Representative and Senator James Blaine and Representative, Senator, and Secretary of the Treasury John Sherman. FAIRMAN, RECONSTRUCTION I, supra note 5, at 1270 (Blaine called Bingham "an effective debater, well informed, ready and versatile"; Sherman described Bingham as one of the "most eloquent" members of the House who "took a leading part in all the debates."). By distinguishing oratory abilities from analytic ones, Fairman sought to credit Blaine and Sherman without discrediting his own evaluation of Bingham. This distinction, however, is artificial and misrepresents the nature of Blaine's and Sherman's praise. Albert Riddle, writing in 1880 but drawing on his experience in Congress between 1861 and 1863, indicated that the Congress was "not a great admirer of eloquence" and that "the mere maker of speeches, is the most useless of men." ALBERT G. Riddle, The Life, Character and Public Service of Jas. A. Garfield 83 (1880). Contrary to Fairman's suggestion, Sherman and Blaine would not have praised Bingham if he had been a "mere maker of speeches."

Moreover, historical evidence reveals that many of Bingham's contemporaries praised his intellectual abilities. See LINUS P. BROCKETT, MEN OF OUR DAY 475 (1868) (indicating that Bingham was regarded as an able lawyer and was especially skilled in cross-examining witnesses); GLYNDOM HowARD [LAURA SEARING], NOTABLE MEN IN THE 'HouSE' 69, 70 (1862) (indicating that Bingham was often spoken of as "the ablest man of the House" of Representatives and that he was a "clear and able" lawyer (emphasis in original)); ALBERT G. RIDDLE, RECOLLECTIONS OF WAR TIMES 115 (1895) (recalling Bingham as "one of our most effective speakers" who the Republicans "usually" put forward as their "champion" in the House of Representatives); WALTER G. SHOTWELl, THE LIFE OF CHARLES SUMNER 597 (1910) (describing Bingham "as a brilliant and effective orator" whose fame "was as wide as his country"). 
Section 2 nor did he explain consistently what rights he believed the Privileges or Immunities Clause of the Fourteenth Amendment would guarantee. While acknowledging that Bingham said he wanted to enforce the "Bill of Rights" against the states, Fairman argued that Bingham used the term "Bill of Rights" not to encompass the provisions of the first eight amendments, but rather to identify the provisions of the Fifth Amendment and Article IV's Privileges and Immunities Clause. This Section argues that Fairman inaccurately portrayed Bingham and distorted his constitutional theory.

Fairman derived the theory he ascribed to Bingham by ignoring the bulk of Bingham's speeches and the context these provide. Instead, Fairman focused on a single speech that Bingham gave before the House of Representatives on February 26, $1866 .{ }^{55}$ This speech was the shortest of all Bingham's speeches on the Fourteenth Amendment, barely filling one and one-half columns of the Congressional Globe. ${ }^{56}$

In this address, Bingham introduced an early version of the new Amendment which would have altered the Constitution to give Congress the power "to secure to the citizens of each State all privileges and immunities of citizens in the several States, and to all persons in the several States equal protection in the rights of life, liberty, and property." ${ }^{157}$ Bingham explained the purpose of the Amendment: "[T]hese great provisions of the Constitution, this immortal bill of rights embodied in the Constitution, rested for its execution and enforcement hitherto upon the fidelity of the States." 58

Fairman summarized the content of the proposal, cited Bingham's concerns that Congress had no power to enforce "this immortal bill of rights," and quoted the first portion of Bingham's speech cited above. ${ }^{59}$ Fairman next provided his interpretation:

Consider Bingham's expression, "these great provisions of the Constitution, this immortal bill of rights embodied in the Constitution." What is the antecedent? Evidently, the "privileges and immunities" (Art. IV, § 2), and the rights of "life, liberty, and property" of the Fifth Amendment-these comprise "the immortal bill of rights." In this spacious gesture Bingham certainly does not seem to be making any particular reference to Amendments I to VIII. Let us take note that, on this occasion at any rate, "the immortal bill of rights" is to Bingham a fine literary phrase not referring precisely to the first eight Amendments. ${ }^{60}$

55. Fairman, supra note 1, at 25-26.

56. Cong. GloBE, 39th Cong., 1st Sess. 1034 (Feb. 26, 1866).

57. Id.

58. Id.

59. Fairman, supra note 1 , at 25 .

60. Id. at 26. 
Fairman insisted that Bingham's reference to "this immortal bill of rights" did not refer to the first eight amendments. ${ }^{61}$ Rather, Fairman suggested, Bingham used the term "immortal bill of rights" to refer to the proposed amendment's protection of a citizen's privileges and immunities and to its protection of the rights to life, liberty and property. The implication is that by using the term immortal bill of rights to encompass both privileges and immunities and life, liberty and property, Bingham indicated that he viewed the protection of life, liberty and property as separate and distinct from the protection of a citizen's privileges and immunities and could not have believed the former to be a component of the latter. And if a citizen's privileges and immunities did not include elements of the Fifth Amendment-the protection of life, liberty and property-it follows that Bingham could not have believed the first eight amendments defined the content of a citizen's privileges and immunities. ${ }^{62}$ As a result, Fairman insisted, Bingham's reference to "this immortal bill of rights" did not refer to the first eight amendments, but rather to two specific provisions of the Constitution. It was this unconventional usage of the term "Bill of Rights" which, in part, led Fairman to conclude Bingham's beliefs were idiosyncratic. ${ }^{63}$

Yet, a more reasonable interpretation of Bingham's February 26 speech exists. An examination of the language of the proposed Amendment shows that its "privileges and immunities" clause would apply only to citizens, whereas its "life, liberty, and property" clause would apply more expansively to "all persons." "It is logical to read the new amendment's protection of life, liberty, and property as representing one privilege and immunity of citizenship - and one worthy of extension equally, not only among citizens but

61. Fairman's reading, in part, depends on Bingham's use of the word "this" rather than "the" preceding the words "bill of rights." By using "this," Bingham may have meant the Bill of .Rights as applied by Article IV, Section 2 and including Fifth Amendment protections. See infra note 71 and accompanying text. It may be that Bingham misspoke or the Congressional Globe erred in its transcription of the speech. Perhaps, as Crosskey has suggested, Bingham held a copy of the Constitution and was gesturing with it when he uttered the word "this." Crosskey, supra note 11, at 28 . Whatever the case, an examination of Bingham's speeches on the Fourteenth Amendment in addition to his February 28, 1866, speech in particular, suggests that Fairman's reading is incorrect.

62. Fairman himself believed that Article IV, Section 2's protection of privileges and immunities could not encompass the first eight amendments. He argued that Article IV could not have included the provisions of the Bill of Rights since the Bill of Rights was adopted after the adoption of Article IV. Fairman, supra note 1, at 61-62. Problems with this argument are threefold. First, the relevant question to determine intent is what the framers of the Fourteenth Amendment believed and intended, not whether their intent was based on a historically correct view of the Constitution. Second, if, as some scholars believe, the Bill of Rights is declaratory, affirming preexisting rights, rather than setting forth new ones, see Amar, supra note 25, at 1205-12, the protections contained in the Bill of Rights could have been privileges and immunities notwithstanding the later adoption of the Bill of Rights. Third, even if, prior to the adoption of the Bill of Rights, Article IV had been confined to privileges and immunities such as the writ of habeas corpus, the adoption of the guarantees in the Bill of Rights arguably expanded the content of federal privileges and immunities. For arguments to this effect, see CONG. GlobE, 42d Cong., 1st Sess. 475 (Apr. 5, 1871) (Speech of Massachusetts Rep. Henry Dawes); Crosskey, supra note 11, at 83.

63. Fairman, supra note 1 , at 26.

64. Cong. Globe, 39th Cong., 1st Sess. 1034 (Feb. 26, 1866). 
to "all persons in the several States." Bingham believed that the content of "this immortal bill of rights" corresponded in content to that of a citizen's privileges and immunities. As the following discussion will show, Bingham believed that both consisted, in significant part, of the first eight amendments.

Bingham's numerous congressional speeches support this second view as the only reasonable interpretation of his February 26 speech. In fact, a comprehensive reading of the historical evidence reveals that Bingham consistently espoused a cogent theory of the content of protected privileges and immunities and the purposes of the Fourteenth Amendment. Bingham's overall theory consisted of four component theories which, for present purposes, will be identified as the national citizenship, Bill of Rights, compact, and enforcement theories. ${ }^{66}$

The national citizenship theory, the first component of Bingham's constitutional theory, holds that the Privileges and Immunities Clause of Article IV, Section 2 protects rights of national rather than state citizenship. In numerous speeches before, during, and after ratification of the Fourteenth Amendment, Bingham argued in support of this theory. In 1859, for example, Bingham opposed the admission of Oregon to the Union because, he argued, while the new state ostensibly would be "free," its constitution excluded African Americans from entering and denied access to the state courts to those who did. ${ }^{67}$ Bingham argued that these provisions in the Oregon Constitution violated the Privileges and Immunities Clause of Article IV, Section 2. He explained that the privileges and immunities protected by Article IV, Section 2 belonged to citizens "in" the several states, and not to citizens "of" the several states. ${ }^{68}$ Bingham's analysis suggests that the second time Article IV, Section 2 refers to the term "citizens," the term may refer to citizens either "of states" or "of the United States." Bingham believed that, properly interpreted, the Clause would read: "The citizens of each State shall be entitled to all

65. Id.

66. Much of the substance of Bingham's views can be found in the transcripts of public statements he made on the floor of Congress. Bingham's hometown newspaper, the Cadiz Republican, reprinted many of his speeches; others were bound in pamphlet form for mass distribution. Since these speeches were intended for circulation among constituents as well, they "provide clues to the sentiments of [those] constituents." KENNETH M. STAMP, AMERICA IN 1857, at viii (1990).

Order Sheets for two of Bingham's speeches suggest that his speeches were widely circulated. See Order sheets, John Bingham Collection, W. Reserve Historical Society, Cleveland, Ohio. There were 6650 reprints of Bingham's January 16, 1867, speech on Reconstruction. Bingham ordered 2000 copies, and 27 others, including Schuyler Colfax and Nathaniel P. Banks, ordered the remaining 4650 copies. Bingham did not order any copies of his closing argument in the Johnson impeachment trial, but 13 other people ordered a total of 2250 copies. Id. See also T. HARRY WILLIAMS, LINCOLN AND THE RADICALS 235 (1965) on the effectiveness of franked political pamphlets.

67. CONG. GlobE, 35th Cong., 2d Sess. 984 (Feb. 11, 1859). See also Speech of Hon. John A. Bingham on the Oregon Bill, CADIZ REPUBLICAN, Mar. 2, 1859, at 1.

68. Cong. GloBe, 35th Cong., 2d Sess. 984 (Feb. 11, 1859). 
privileges and immunities of citizens [of the United States] in the several States." 69

The consequences of this reading are important. The alternative reading that the terms "of citizens" means "of state citizens" renders Article IV, Section 2 a variant equal protection clause, simply requiring a state to treat equally its own citizens and the citizens of other states within its borders. By contrast, if the reference is to "citizens of the United States," then the provision implies the existence of substantive national rights which states may not deny. Bingham articulated the latter interpretation of Article IV, Section 2 in seven additional congressional speeches between 1861 and $1868^{70}$

The Bill of Rights theory, the second component of Bingham's constitutional theory, argues that the privileges and immunities of U.S. citizens include, at a minimum, the provisions of the Bill of Rights. ${ }^{71}$ While Bingham often referred to certain of these provisions individually, ${ }^{72}$ he believed that

69. Id. Contra Dred Scott v. Sandford, 60 U.S. (19 How.) 393, 527 (1857) (Catron, J.).

70. CONG. GloBE, 39th Cong., 2d Sess. 450 (January 14, 1867) (paraphrasing Article IV, Section 2 and stating "“. . . all privileges and immunities of citizens' [of the United States] (supplying the ellipsis) "in the several States.") (bracketed and parenthetical language in original); CONG. GLOBE, 39th Cong., Ist Sess. 2542 (May 10, 1866) ("No States ever had the right ... to abridge the privileges or immunities of any citizen of the Republic."); CONG. GLOBE, 39th Cong., 1st Sess. 1089 (Feb. 28, 1866) (suggesting that there is no authority supporting the contention "that any State has the right to deny to a citizen of any other State any of the privileges or immunities of a citizen of the United States."); CONG. GLOBE, 39th Cong., 1st Sess. 158 (Jan. 9, 1866) ("This guarantee is of the privileges and immunities of citizens of the United States in, not of, the several States."); ConG. Globe, 37th Cong., 2d Sess. 1639 (Apr. 11, 1862) ("The great privilege and immunity of an American citizen"); CONG. GLOBE, 36th Cong., 2d Sess. app. at 80-84 (Jan. 22, 1861) (referring to "the privileges and immunities of American citizens in the several states"); see also Speech of Hon. Jno. A. Bingham, CADIZ RePubliCAN, Jan. 24, 1866, at 1 (reprinting Bingham's January 9, 1866, congressional speech). After ratification of the Fourteenth Amendment, Bingham, referring back to the admission of Missouri to the Union, insisted that the new state not violate the Privileges and Immunities Clause of Article IV. Bingham stated that Congress required that Missouri's constitution never "deprive any citizen of the United States of the rights and privileges of a citizen of the United States within the limits of that State." (emphasis added). He stated that the Fourteenth Amendment "secures this power to the Congress of the United States." CONG. GlobE, 40th Cong., 2d Sess. 2462-63 (1868). But see 3 STAT. 645 (1821) (indicating that Bingham's recollection of Congress' wording in the 1821 statute admitting Missouri to the union was incorrect).

In 1871, Bingham recalled the Constitution "as it was" prior to the Fourteenth Amendment and indicated that states did not have the right to enact laws "which abridged the privileges or immunities of the citizens of the United States, as guaranteed by the Constitution of the United States." Speech of Hon. John A. Bingham at Belpre, Ohio, September 14, 1871, CADIZ REPuBLICAN, Sept. 28, 1871, at 1 (emphasis added).

71. Crosskey, supra note 11, at 27-28; CuRTIS, supra note 24, at 58-71.

72. For instance, in 1862 Bingham stated, "The great privilege and immunity of. . American citizen[s] to be respected everywhere in this land ... is that they shall not be deprived of life, liberty, or property without due process of law." CONG. GLOBE, 37th Cong., 2d Sess. 1639 (1862). On other occasions Bingham suggested that among the privileges and immunities protected by Article IV, Section 2 were the rights to freedom of speech, press, conscience, assembly, trial by jury, and the right to bear arms. Speech of Hon. John A. Bingham at Belpre, Ohio, September 14, 1871, supra note 70, at 1 . He also included the rights protected under the Seventh Amendment, CONG. GLOBE, 39th Cong. 1st Sess., 1089-90 (Feb. 28, 1866), and the Eighth Amendment. CONG. GloBE, 39th Cong., 2d Sess. 811 (Jan. 28, 1867). In 1866, Bingham spoke of the violation of "guarantied [sic] privileges of citizens of the United States" and included the infiction of "cruel and unusual punishments" under state law as "[c]ontrary to the express letter of your Constitution." CoNG. GloBE, 39th Cong., 1st Sess. 2542 (May 10, 1866). In January, 1867, Bingham identified the Fifth Amendment Just Compensation Clause and the provisions of the Eighth Amendment as "personal rights," CONG. GLOBE, 39th Cong., 2d Sess. 811 (Jan. 28, 1867), and looked to the ratification 
the privileges and immunities of national citizenship encompassed all the provisions of the first eight amendments. As he stated in 1871, "[T]he privileges and immunities of citizens of the United States, as contradistinguished from citizens of a State, are chiefly defined in the first eight amendments to the Constitution of the United States."73

The third component of Bingham's constitutional theory, the compact theory, holds that even before the adoption of the Fourteenth Amendment, the Constitution prohibited states from abridging the first eight amendments. According to Bingham, Article IV, Section 2 applied the provisions of the Bill of Rights against the states, but the absence of an express clause granting Congress enforcement authority meant that while a compact existed that bound the states to comply with Section Two, no remedy was available when the states breached this obligation. For instance, in 1866, Bingham insisted that the states had no right to "abridge the privileges or immunities of any citizen of the Republic," and yet they had done so without repercussion, since Congress lacked the authority to prevent such action. ${ }^{74}$

Fairman correctly noted that Bingham believed that Article IV, Section 2 barred the states from abridging the privileges and immunities guaranteed by the Section, and that Congress had no enforcement authority. ${ }^{75}$ Yet since Fairman misunderstood Bingham's national citizenship and Bill of Rights theories, Fairman minimized the importance of the compact theory. Fairman did not acknowledge that, under the compact theory, the Constitution imposed on the states an unenforceable obligation to guarantee, at a minimum, the first eight amendments.

The final component of Bingham's constitutional theory, the enforcement theory, holds that the Fourteenth Amendment provides the enforcement power absent from Article IV, Section 2. Bingham, in his speeches preceding, during, and after the Amendment's ratification, consistently and repeatedly stated that the new Amendment's purpose was to enforce the Bill of Rights against the states.

On January 25, 1866, two years before the adoption of the Fourteenth Amendment, Bingham made clear his belief that the federal government should be empowered to enforce the Bill of Rights against the states. Bingham spoke in general terms about what was to become the Fourteenth Amendment, then pending before the Joint Committee on Reconstruction. ${ }^{76} \mathrm{He}$ said it was a

of the Fourteenth Amendment to enforce "all the limitations for personal protection of every article and section of the Constitution." Id.

73. CONG. GLOBE, 42d Cong., 1st Sess. app. at 84 (Mar. 31, 1871) (emphasis added). In Adamson, Justice Black recognized that Bingham believed that the first eight amendments to the Constitution "chiefly defined" the privileges and immunities of U.S. citizenship. 332 U.S. at 115 app. (Black, J., dissenting). See supra notes 35-39 and accompanying text.

74. CONG. GLOBE, 39th Cong., 1st Sess. 2542 (May 10, 1866).

75. Fairman, supra note 1 , at 25-26.

76. Cong. Globe, 39th Cong., 1st Sess. 429 (Jan. 25, 1866). 
"general" amendment which would give Congress the express power to enforce "the rights which were guarantied [sic] ... from the beginning, but which guarantee has unhappily been disregarded by more than one State of this Union, ... simply because of a want of power in Congress to enforce that guarantee." 77

One month later Bingham said that the Fourteenth Amendment would "arm the Congress . . . with the power to enforce the bill of rights as it stands in the Constitution today." ${ }^{\text {"78 }}$ Bingham specifically stated that the Fourteenth Amendment was needed to overcome the effects of Barron v. Baltimore ${ }^{79}$ and Livingston $v$. Moore ${ }^{80}$ which had held, respectively, that the Fifth and Seventh Amendments did not limit the states. ${ }^{81}$ Bingham stated, "Gentlemen admit the force of the provisions in the bill of rights, that the citizens of the United States shall be entitled to all the privileges and immunities of citizens of the United States in the several States." ${ }^{82}$ Bingham said that Barron $v$. Baltimore "makes plain the necessity of adopting this amendment." ${ }^{13}$ The pamphlet version of Bingham's speech on the floor of Congress was subtitled a speech "in support of the proposed amendment to enforce the bill of rights." 84

On March 9, 1866, Bingham voiced his opposition to the pending Civil Rights Bill. Bingham stated that "the enforcement of the bill of rights is the want of the Republic." 85 Bingham and James Wilson debated whether Congress already had the authority to pass legislation enforcing the Bill of Rights or whether, as Bingham believed, a constitutional amendment was necessary. ${ }^{86}$ Bingham said that he wanted the federal Bill of Rights "enforced everywhere" and that this goal could be accomplished only by a constitutional amendment. ${ }^{87} \mathrm{He}$ said that he advocated an amendment "which would arm Congress with the power to compel obedience to the oath, and punish all

77. Id.

78. CONG. GloBe, 39th Cong., 1st Sess. 1088 (Feb. 28, 1866).

79. 32 U.S. (7 Pet.) 243 (1833).

80. 32 U.S. (7 Pet.) 469 (1833).

81. ConG. GloBe, 39th Cong., 1st Sess. 1089-90 (Feb. 28, 1866).

82. Id. at 1089 (emphasis added).

83. Id.

84. JoHn A. BINGHAM, ONE COUNTRY, ONE CONSTITUTION, AND ONE PEOPLE. SPEECH OF HON. JOHN A. BINGHAM, OF OHIO, IN THE HOUSE OF REPRESENTATIVES, FEB. 28, 1866, IN SUPPORT OF THE PROPOSED AMENDMENT TO ENFORCE THE BILL OF RIGHTS (Washington, Printed at the Congressional globe [sic] office, 1866) (on file at Library of Congress). The New York Times reported a summary of Bingham's February 28, 1866, speech and noted Bingham's belief regarding the purpose of the proposed Amendment. "This was simply a proposition to arm the Congress of the United States ... with power to enforce the Bill of Rights as it stood in the Constitution." N.Y. TIMES, Mar. 1, 1866, at 5.

85. CONG. GLOBE, 39th Cong., 1st Sess. 1291 (Mar. 9, 1866). This speech was summarized and distributed in pamphlet form. See The Civil Rights Bill, N.Y. TIMES, Mar. 10, 1866, at 1. Ohio Representative Lawrence noted that Bingham's March 9 speech had been "extensively published." CoNG. GLOBE, 39th Cong., 1st Sess. 1837 (Apr. 7, 1866).

86. See The Civil Rights Bill, supra note 85, at 1.

87. Cong. GLOBE, 39th Cong., 1st Sess. 1291 (Mar. 9, 1866). 
violations by State officers of the bill of rights, but leaving those officers to discharge the duties enjoined upon them as citizens of the United States by that oath and by that Constitution." 88

On May 10, 1866, Bingham gave the last major speech in the House of Representatives in favor of the adoption of the Fourteenth Amendment. ${ }^{89}$ While he directed much of his speech toward the apportionment provisions of Section Two and the disenfranchisement provisions of Section Three, ${ }^{90}$ his remarks concerning Section One reiterated his conviction that the Amendment would enforce the Bill of Rights against the states. He explained that the Amendment provided:

by express authority of the Constitution to do that by congressional enactment which hitherto they have not had the power to do, and have never even attempted to do; that is, to protect by national law the privileges and immunities of all the citizens of the Republic and the inborn rights of every person within its jurisdiction whenever the same shall be abridged or denied by the unconstitutional acts of any State..$^{91}$

By using the word "abridge," Bingham suggested that the Amendment would not create new privileges or immunities. ${ }^{92}$ Rather, its purpose was to protect, by creating an enforcement power, existing privileges and immunities.

After the ratification of the Fourteenth Amendment, Bingham, speaking on behalf of a majority of the House Judiciary Committee, summarized his constitutional theory:

The fourteenth amendment, it is believed, did not add to the privileges or immunities before mentioned, but was deemed necessary for their enforcement as an express limitation upon the powers of the States. It had been judicially determined that the first eight articles of amendment of the Constitution were not limitations on the power of the States, and it was apprehended that the same might be held of the provision of the second section, fourth article. ${ }^{93}$

88. Id. at 1292 (emphasis added). Though this speech was made in the House, the Senate was aware that Bingham had authored Section One of the Fourteenth Amendment and that he had expressed the desire to enforce the Bill of Rights against the states in his speech on the Civil Rights Bill. See Amar, supra note 25, at 1238 n.200. Thus, even before Senator Howard's May 23, 1866, speech introducing the Amendment, the Senate knew that Bingham intended the Fourteenth Amendment to enforce the Bill of Rights against the states. See also CoNG. GlobE, 42d Cong., 1st Sess. app. at 256 (Apr. 13, 1871) (Sen. Henry Wilson concurring with Bingham's view of the Fourteenth Amendment and referring to Bingham as Amendment's author).

89. Cong. Globe, 39th Cong., 1st Sess. 2541 (May 10, 1866).

90. Id. at $2541-42$.

91. Id. at 2542 .

92. See also Amar, supra note 25, at 1219-20.

93. H.R. REP. No. 22, 41 st Cong., 3d Sess. (Jan. 30, 1871), reprinted in THE RECONSTRUCTION AMENDMENTS' DEBATES 466-67 (Alfred Avins ed., 1967). Bingham did not refer to specific "judiciai[] determin[ations]" but was undoubtedly referring to Barron v. Baltimore, 32 U.S. (7 Pet.) 243 (1833), and 
In March, 1871, Bingham stated explicitly that the Fourteenth Amendment was designed to apply the Bill of Rights to the states. Noting that the first eight amendments "chiefly defined" the privileges and immunities of U.S. citizenship, Bingham stated, "These eight articles I have shown never were limitations upon the power of the States, until made so by the fourteenth amendment." 94

Taken together, this textual and contextual review shows that Bingham held a clear constitutional theory and that he intended to use the Privileges or Immunities Clause of the Fourteenth Amendment to enforce the Bill of Rights against the states. Fairman reached the opposite conclusion only by narrowly focusing on and misreading Bingham's February 26, 1866, speech and ignoring the context provided by Bingham's other relevant speeches.

\section{How “SingUlaR” Were BinghaM's VIEWs?}

Fairman argued that Bingham's understanding of the Fourteenth Amendment was not only confused but also "novel." 95 According to Fairman, "[a] careful reader will have remarked that [Bingham] held a singular opinion on the constitutional problem."96 In 1971 Fairman described Bingham as having a "peculiar mode of thought."

However, the historical evidence reveals that Bingham's views of the Constitution and the Fourteenth Amendment were not idiosyncratic. Elements of his national citizenship, Bill of Rights, compact, and enforcement theories can be found in traditional antislavery theory, ${ }^{98}$ and in the opinions of wellknown lawyers, judges, and political leaders. During speeches on the floor of the House and Senate, several congressional leaders espoused positions consistent with Bingham's theories. The authors of three contemporary legal treatises each shared Bingham's view concerning the purpose of the Fourteenth Amendment.

\section{A. Antislavery Constitutionalism}

Many antislavery activists shared Bingham's national citizenship, Bill of Rights, and compact Theories. A major tenet of antislavery constitutionalism held that the guarantees of the Bill of Rights were among Article IV's privileges and immunities and that all the provisions of Article IV, except the

\footnotetext{
Livingston v. Moore, 32 U.S. (7 Pet.) 469 (1833). In his February 28, 1866, speech, Bingham cited these cases when asserting the same position. See CONG. GLOBE, 39th Cong., 1st Sess. 1089-90 (Feb. 28, 1866).

94. ConG. GloBE, 42d Cong., 1st Sess. app. at 84 (Mar. 31, 1871).

95. Fairman, supra note 1 , at 26.

96. Id. at 25 (emphasis added).

97. FAIRMAN, RECONSTRUCTION I, supra note 5, at 1270.

98. For an account of Bingham's antislavery background, see generally Richard L. Aynes, The Antislavery and Abolitionist Background of John A. Bingham, 37 CATH. U. L. REV. 881 (1988).
} 
Full Faith and Credit Clause, were part of a compact with the states. According to this theory, the Constitution commanded state adherence to these provisions even though Congress lacked the power to enforce these rights against state infringement. ${ }^{99}$

Commentators advanced this theory as early as 1834 , and lawyers and judges on both sides of the debate presented arguments in the decades that followed. ${ }^{100}$ For example, New Jersey Supreme Court Chief Justice Joseph C. Hornblower adopted this view in State v. Sheriff of Burlington in 1836. ${ }^{101}$ Salmon P. Chase and James G. Birney in Ohio advanced the same argument in the Matilda case ${ }^{102}$ and in State v. Hoppess. ${ }^{103}$ Chase refined it before the U.S. Supreme Court in Jones $v$. Van Zandt. ${ }^{104}$

In his 1859 argument before the Ohio Supreme Court in Ex parte Bushnell, ${ }^{105}$ Ohio Attorney General Christopher P. Wolcott presented the most sophisticated version of the theory that Congress lacked power to enforce Article IV's Privileges and Immunities Clause. ${ }^{106}$ Attorney General Wolcott discussed the history and origins of Article IV and concluded that the Fugitive

99. Howard J. Graham, The Early Antislavery Backgrounds of the Fourteenth Amendment, 1950 Wis. L. REV. $479,493$.

100. TENBROEK, supra note 8, at 61-62 n.6.

101. The New Jersey Supreme Court heard State v. Sheriff of Burlington in 1836. Petitioners sought the return of an alleged fugitive slave residing in New Jersey. Chief Justice Hornblower's opinion considered the constitutionality of the federal fugitive slave law of 1793 and suggested that the federal government could enforce no part of Article IV other than the Full Faith and Credit Clause. He nevertheless decided in favor of the alleged fugitive, basing his decision on New Jersey's 1826 fugitive slave law. See OPINION OF CHIEF JUSTICE HORNBLOWER ON THE FUgITIVE SLAVE LAW, reprinted in 1 FUGITIVE SLAVES AND AMERICAN CourTs 99-103, in 2 SLAVERY RACE AND THE AMERICAN LEGAL SYSTEM 1700-1872 (Paul Finkelman ed., 1988); see also Paul Finkelman, State Constitutional Protections of Liberty and the Antebellum New Jersey Supreme Court: Chief Justice Hormblower and the Fugitive Slave Law, 23 RUTGERS LJ. 753, 768-74 (1992).

102. This case was not reported. Chase's argument is summarized in PAUL FINKELMaN, SLAVERY IN THE COURTROOM 31-32 (1985) and HAROLD H. HyMAN \& William M. WiECEK, EQUAL JuSTICE UNDER LAW 107 (1982). Chase later suggested that he had independently reached the same conclusions as did Chief Justice Hornblower in Sheriff of Burlington, but that his confidence in this view had been "greatly strengthened" by seeing a "brief" newspaper account of the decision. Letter from Salmon P. Chase to Chief Justice R.S. Field (Apr. 9, 1865), in ROBERT B. WARDEN, AN ACCOUNT OF THE PRIVATE LIFE AND PUBLIC SERVICES OF SALMON P. CHASE 637 (1874).

103. 2 W.L.J. 279, 289 (Ohio 1845).

104. Jones v. Van Zandt, 46 U.S. (5 How.) 215 (1847). Chase's argument was published in pamphlet form and is summarized in 4 W.L.J. 321-328 (1846).

105. 9 Ohio St. 77 (1859).

106. Id. at 97-181. Bingham and Chase were longtime allies in Ohio Republican politics, see, e.g., Letter from John A. Bingham to Salmon P. Chase (May 11, 1858) (Chase Manuscript Collection, Library of Congress) (indicating support of Chase for President), and Bingham very likely knew Wolcott. Wolcott studied law in the offices of Edwin Stanton and later served as his Assistant Secretary of War. 1 BENCH AND BAR OF OHIO 417-18 (George I. Reed ed., 1897). In 1856, Governor Salmon P. Chase appointed Wolcott Attorney General of Ohio. Wolcott was subsequently elected and served two terms. 1 THE HistoRY OF THE REPUBLICAN PARTY IN OHIO 65, 67, 84 (John. P. Smith ed., 1898) [hereinafter REPUBLICAN PARTY OF OHIO]. Wolcott was a delegate to the first National Republican Convention in 1856, $i d$. at 53, and one of the four people Chase named to represent his interests at the 1860 National Republican Convention. DonNal V. SMITH, CHASE AND CIVIL WaR Polmitis 13, 72, 80-83 (1931). During the Civil War, Wolcott served as Judge Advocate General for Ohio's militia. Rowland H. RERICK, STATE CENTENNIAL HISTORY OF OHIO 318 (1902). 
Slave Clause was "one of compact merely" 107 because no express provision delegated enforcement authority to Congress. ${ }^{108} \mathrm{He}$ called the Clause part of a compact because its "execution ... rests with the states alone."109

Wolcott pointed out that, by contrast, the Constitution included a congressional enforcement power for the Full Faith and Credit Clause. ${ }^{110}$ Wolcott argued that this specific grant of power to Congress demonstrated that when the framers intended Congress to have a given power, they granted the power expressly. In his view, the lack of express power to enforce the other provisions of Article IV meant no such power existed. ${ }^{111}$ As a result, Congress could not compel states to return fugitive slaves. Though the threeperson majority in Bushnell did not adopt Wolcott's argument, Wolcott's reasoning won the votes of dissenting Judges Brinkerhoff and Sutliff. ${ }^{112}$

Thus, antislavery constitutional theory held that the absence of specific provisions giving the federal government the power to enforce the Privileges and Immunities Clause, the Fugitive Slave Clause, and the Fugitive from Justice Clause meant that those clauses set forth duties enjoined on the states but unenforceable by the federal government. Certainly, this view was not undisputed. The Supreme Court rejected it with respect to the Fugitive Slave Clause in Prigg v. Pennsylvania. ${ }^{113}$ But antislavery lawyers like Chase,

107. 9 Ohio St. at 122-23.

108. Some modern commentators have also referred to the provisions of Article IV as "a collection of compactlike clauses." See, e.g., HYMAN \& WIECEK, supra note 102, at 151.

109. 9 Ohio St. at 113-15.

110. "Full Faith and Credit shall be given in each State to the public Acts, Records, and judicial Proceedings of every other State; And the Congress may by general Laws prescribe the Manner in which such Acts, Records and Proceedings shall be proved, and the Effect thereof.' U.S. CONST. art. IV, § 1.

111. 9 Ohio St. at 133-34; see KERMTT L. HALl ET AL., AMERICAN LEGAL HISTORY 201 (1991) ("The fugitive slave clause's wording and its placement of Article IV, $\S 2$, of the Constitution suggest that the Framers did not anticipate a federal law to enforce it."); see also James B. White, Constructing a Constitution: Original Intention in the Slave Cases, 47 MD. L. REv. 239, 245 n.13 (1988) (acknowledging that absence of express enforcement provisions in Sections Two and Four of Article IV "might reasonably be read as significant omission[]").

112. 9 Ohio St. at 225-27 (Brinkerhoff, J., dissenting), 234-36 (Sutliff, J., dissenting). Judge Brinkerhoff concluded that most of Article IV's provisions were "mere articles of compact between the states" and that they did not give Congress "any power whatsoever" to enforce those provisions. Id. at 225. Similarly, Judge Sutliff adopted Wolcatt's argument that only the states had the authority to enforce the Fugitive Slave Clause. Id. at 234-36. To show the impropriety of federal enforcement, Sutliff indicated that if the federal government could enforce the Fugitive Slave Clause, then it could also enforce the Privileges and Immunities Clause. Id. at 234. Justice Sutliff's opinion was reprinted in pamphlet form for mass distribution. Dissenting opinion of Hon. Milton Sutliff, One of the Judges, Ex parte Simeon Bushnell, Ex Parte Charles Langston (n.p. 1859), reprinted in 4 FugITIVE SLAVES AND AMERICAN COURTS, supra note 99, at 23.

113. Prigg v. Commonwealth of Pennsylvania, 41 U.S. (16 Pet.) 539 (1842). See generally Paul Finkelman, Prigg v. Pennsylvania and Northern State Courts: Anti-Slavery Use of a Pro-Slavery Decision, 25 CIV. WAR HIST. 5 (1979). The Court held that while the federal government could enforce the Fugitive Slave Clause directly, it could not force state officers to enforce the Clause. Prigg, 41 U.S. (16 Pet.) at 615. Thus, Prigg upheld federal legislation notwithstanding the lack of specific authority for its passage. Id. at 615-16.

Fairman concluded that because the Supreme Court in Prigg upheld the constitutionality of the federal Fugitive Slave Law, Bingham erred when he argued that Article IV's Privileges and Immunities Clause could not be enforced. FAIRMAN, RECONSTRUCTION I, supra note 5, at 1276. Yet, Fairman did not acknowledge as inconsistent with Prigg the Court's decision in Commonwealth of Kentucky v. Dennison, 
Wolcott, and Bingham, and antislavery judges like Ohio Supreme Court Judges Brinkerhoff and Sutliff rejected this aspect of Prigg just as they rejected Dred Scott. ${ }^{114}$

The political aftermath of the Bushnell decision demonstrates that, at least in Ohio, a great deal of popular support existed for Bingham's view of the Constitution. The three-to-two majority rejecting the antislavery view consisted of two Democrats and one Republican, Chief Judge Joseph R. Swan. While Swan had previously enjoyed considerable popularity and prestige, ${ }^{115}$ the Republican Convention of 1859 denied Swan renomination by a vote of 217 to $140 .^{116}$

While Swan was repudiated, dissenting Judge Brinkerhoff was celebrated. A well-known Free-Soil Democratic Congressman prior to his service on the Court, Brinkerhoff was re-nominated and re-elected to the Court twice after the publication of his dissent in Bushnell, once in 1860, and again in 1864. ${ }^{117}$ According to one historian, the "entire issue" of Brinkerhoff's 1860 re-election campaign was his judicial opposition to the 1850 Fugitive Slave Law. ${ }^{118}$ Brinkerhoff's sweeping 1860 victory was the Ohio Republican Party's "most brilliant one" up to that time. ${ }^{119}$

Support for Bingham's compact theory was not confined to Ohio. Attorney General Wolcott, arguing before the U.S. Supreme Court in Commonwealth of Kentucky v. Dennison, ${ }^{120}$ pursued portions of this argument as it applied to the Fugitive from Justice Clause of Article IV, Section Two. Chief Justice Taney, writing for a unanimous Court in Dennison, referred to Article IV, Section Two as a "compact"121 in words that echoed Wolcott's argument in Ex parte Bushnell. While concluding that the Governor of Ohio was bound to

65 U.S. (24 How.) 66 (1861), which held that the Fugitive from Justice Clause of Art. IV, Section 2 was unenforceable. FAIRMAN, RECONSTRUCTION I, supra note 5, at 394.

114. Dred Scott v. Sandford, 60 U.S. (19 How.) 393 (1857).

115. Swan was one of the founders of the Ohio Republican Party and had presided over its first state convention. He was nominated for the Ohio Supreme Court by acclamation, and was elected to the court in 1854 by a substantial majority of the votes cast. REPUBLICAN PARTY OF OHIO, supra note 106, at 9, 13, $24,27$.

116. Id. at 90 .

117. Id. at 209; 3 DICTIONARY OF AMERICAN BIOGRAPHY 49 (Allen Johnson ed., 1929).

118. Paul Finkelman, Prelude to the Fourteenth Amendment: Black Legal Rights in the Antebellum North, 17 RUTGERS L.J. 415, 461 (1986).

119. Id. at 461 (quoting EugENE ROSEBOOM, A HistoRY OF THE STATE OF OHIO: THE Civil WAR ERA 371 (1978)). Further evidence of support for the compact theory can be found in the Ohio Republican Party's platform of 1859. The platform was prepared by the Convention's Committee on Resolutions, which Bingham chaired. The OHIo PlatFormS OF THE REPUBLICAN AND DEMOCRATIC PARTIES From 1855 to 1881 INCLUSIVE (1881) [hereinafter OHIO PLATFORMS]. "[P]artly inspired" by Bushnell, REPUBLICAN PARTY OF OHIO, supra note 106, at 90 , the platform demanded the repeal of the Fugitive Slave Act of 1850 , calling the legislation "subversive of both the rights of the States and the liberties of the people." OnIO PLATFORMS, supra, at 9. In the election of 1859, Republican candidate William Y. Gholson narrowly defeated his Democratic opponent, in what amounted to a referendum on Bushnell. REPUBLICAN PARTY OF OHIO, supra note 106 , at $94-95$.

120. 65 U.S. ( 24 How.) 66, 90-93 (1859), overruled by Puerto Rico v. Branstad, 483 U.S. 219 (1987).

121. Id. at 109. 
deliver the fugitive, Taney stated that "there is no power delegated to the General Government ... to use any coercive means to compel him" to do so. ${ }^{122}$ Indeed, according to Chief Justice Taney, Article IV, Section Two was

declaratory of the moral duty which this compact created when Congress had provided the mode of carrying it into execution. The act does not provide any means to compel the execution of this duty ... nor is there any clause or provision in the Constitution which arms the Government of the United States with this power. ${ }^{123}$

Thus, Bingham's compact theory coincided with fundamental tenets of antislavery theory and, on at least one occasion, a decision of the U.S. Supreme Court. Prominent judges, lawyers, and members of Congress shared Bingham's conviction that the Constitution prohibited the states from abridging the privileges and immunities protected by Article IV, Section 2, but that Congress could not enforce the provision. ${ }^{124}$

\section{B. Political and Popular Perspectives}

Contemporary statements by politicians and the popular press refute Fairman's claim that Bingham's constitutional theory was singular. For instance, this evidence reveals that Bingham's national citizenship theory was not unique. Among Bingham's contemporaries concurring with his view that privileges and immunities were elements of national citizenship were Michigan Senator Jacob Howard, ${ }^{125}$ Ohio Congressman William Lawrence, ${ }^{126}$ Ohio

122. Id. at 109-10.

123. Id. at 107. Dennison may have reflected an effort by the Court to support the theory that even though the states did not have the right to secede, the federal government did not have the right to use force to keep them in the Union. See Paul Finkelman, States' Rights North and South in Antebellum America, in AN UNCERTAIN TRADITION, CONSTITUTIONALISM AND THE HISTORY OF THE SOUTH 146 (Kermit L. Hall \& James W. Ely, Jr. eds., 1989). Regardless of the motivation, the legal principles the Court announced coincided with antislavery legal theory and Bingham's compact theory.

124. After the Civil War, some antislavery activists modified aspects of this constitutional theory. For instance, during the debates on the 1866 Civil Rights Bill, Representative Wilson of Iowa pragmatically accepted the pro-slavery decisions of the Taney Court. Wilson argued that if Prigg v. Pennsylvania, 41 U.S. (16 Pet.) 539 (1842), authorized enforcement of the Fugitive Slave Clause, the decision was precedent which demonstrated the legitimacy of the Civil Rights Bill. CONG. GLOBE, 39th Cong., 1st Sess. 1118 (1866) ("We will turn the artillery of slavery upon itself.") Senator Trumbull made similar arguments in the Senate. Id. at 605. Thus Wilson and Trumbull agreed with Bingham that the Bill of Rights applied to the states through Article IV, Section 2, but both argued that Congress already had an enforcement power. Id. at 1118, 1294; see also Curtis, supra note 24, at 80-81; Crosskey, supra note 11, at $46-47$ (discussing Wilson's and Bingham's views of the Civil Rights Bill).

125. Senator Howard, in a speech on the Fourteenth Amendment, referred to Article IV, Section 2, as applying to "citizen[s] of the United States." CONG. Globe, 39th Cong., 1st Sess. 2764-68 (May 23, 1866). While Fairman concluded that "Howard spoke inaccurately," FAIRMAN, RECONSTRUCTION I, supra note 5, at 1291, 1294, Howard, like Bingham, may have thought that the Article IV language "citizens in the several states" should be read as "citizens of the United States in the several states." See infra note 69 and accompanying text.

126. During the debate over the Civil Rights Bill, Ohio Congressman Lawrence explained that "the citizens of each State' if they remove from one State to another 'shall be entitled to all privileges and 
Senator John Sherman, ${ }^{127}$ Indiana Senator Henry S. Lane, ${ }^{128}$ several Radical Republicans, ${ }^{129}$ and, perhaps, Ohio Congressman and future President Garfield. ${ }^{130}$ Justice Bradley subsequently articulated a similar position in his dissent in the Slaughter-House Cases. Bradley wrote, "It is pertinent to observe that ... the clause of the Constitution referred to ... speak[s] of the privileges and immunities of citizens in a State; not of citizens of a State."131

Many prominent contemporaries of Bingham also shared his Bill of Rights theory, believing that the privileges and immunities of U.S. citizens included the provisions of the Bill of Rights. In 1864, James Wilson, Chairman of the House Judiciary Committee, Representatives John Kasson and John F. Farnsworth all stated that the provisions of the Bill of Rights "defined the 'privileges and immunities' of state and national citizens."132 Wilson stated that the First Amendment was only one of "many . . . constitutional rights of the citizen" which were protected under Art. IV, Section $2 .{ }^{133}$ Republican Representative Sidney Clarke of Kansas expressed the same interpretation of "privileges and immunities" on the floor of Congress. ${ }^{134}$ After the adoption

immunities of citizens' of the United States 'in the' State to which they remove." CONG. GLOBE, 39th Cong., 1st Sess. 1836 (Apr. 7, 1866).

127. In speaking of Article IV, Section 2, Sherman referred to exercising "the immunity of a citizen of the United States." TENBROEK, supra note 8, at 185-86 n.14.

128. Senator Lane maintained that African Americans were "entitled to all the privileges and immunities of other free citizens of the United States." Id. at 186 n.14.

129. See, for example, the petition directed to Congress by Radical Republican Rev. George B. Cheever, Edward Gilbert, and Parker Pillsbury. THe Reverend George B. Cheever AND OTHERS, PetiTion, (Nov. 30, 1865), reprinted in THE RAdICAL RePUBLICANS AND RECONSTRUCTION, 1861-1870, at 280 (Harold M. Hyman ed., 1967).

130. In the debate over the Freedman's Bureau Bill, Garfield stated:

In reference to persons, we must see to it, that hereafter, personal liberty and personal rights are placed in the keeping of the nation; that the right to life, liberty, and property shall be guarantied [sic] to the citizen in reality as they now are in the words of the Constitution, and no longer left to the caprice of mobs or the contingencies of local legislation. If our Constitution does not now afford all the powers necessary to that end, we must ask the people to add them. We must give full force and effect to the provision that "no citizen shall be deprived of life, liberty, or property without due process of law." We must make it as true in fact as it is in law, that "the citizens of each State shall be entitled to all the privileges and immunities of citizens in the several States." We must make American citizenship the shield that protects every citizen, on every foot of our soil.

CONG. GLOBE, 39th Cong., Ist Sess. app. at 67 (Feb. 1, 1866). In contemplating a possible constitutional amendment, Garfield may have viewed the Fifth Amendment as providing the sole content of a citizen's privileges and immunities. Yet, Garfield's references placing "personal liberty and personal rights" within national protection and to "American citizenship" suggest that Garfield, like Bingham, may have read the Privileges and Immunities Clause of Article IV, Section 2 to protect the rights of U.S., not state, citizenship. He may have viewed the provisions of the Fifth Amendment as representing some but by no means all the privileges and immunities of U.S. citizens.

131. 83 U.S. (16 Wall) 36,117 (1872) (Bradley, J., dissenting). Two generations later, Justice Roberts, while accepting the interpretation that Article IV, Section 2 merely prohibited discrimination against citizens of other states, noted that earlier some people had thought that "the purpose of the section was to create rights of citizens of the United States" by guaranteeing natural rights. Hague v. CIO, 307 U.S. 496, 511 (1939) (emphasis added).

132. Curtis, supra note 24, at 61-64; see also CurTIs, supra note 24, at 37-38; HYMAN \& WIECEK, supra note 102, at 404 (citations omitted).

133. CONG. GLOBE, 38th Cong., 1st Sess. 1202 (March 19, 1864)

134. HYMAN \& WIECEK, supra note 102 , at 405. 
of the Fourteenth Amendment, ten Representatives and three Senators expressly stated that they believed that the privileges and immunities of national citizenship included the protections of the Bill of Rights. ${ }^{135}$

Adoption of the $1871 \mathrm{Ku} \mathrm{Klux} \mathrm{Klan} \mathrm{Act} \mathrm{demonstrated} \mathrm{congressional}$ concurrence with Bingham's enforcement theory, as well. Proponents of the statute had argued that the Fourteenth Amendment guaranteed the protections of the Bill of Rights against the states whereas opponents of the Act argued that Barron v. Baltimore was still controlling. ${ }^{136}$

In 1874, Kentucky Democrat James B. Beck stated that the Fourteenth Amendment applied the Bill of Rights to the states. ${ }^{137}$ In evaluating Beck's speech, historian Eric Foner wrote that "by 1874 this had become a virtually noncontroversial minimum Congressional interpretation of the Amendment's purposes." 138

Aspects of Bingham's compact and enforcement theories are evident in a Senate resolution of February 1, 1866. This provided that the Joint Committee on Reconstruction, of which Bingham was a member, should

inquire into the expediency of amending the Constitution of the United States so as to declare with greater certainty the power of Congress to enforce and determine by appropriate legislation all the guarantees contained in that instrument, and more especially, . . that which assures the citizens of each State all privileges and immunities of citizens in the several States. ${ }^{139}$

The Senate likely chose the words "greater certainty" to embrace both those who, like Wilson, thought the enforcement power existed even though it had not been used effectively; and those who, like Bingham, believed no enforcement power existed in the Constitution. ${ }^{140}$

135. See THE RECONSTRUCTION AMENDMENTS' DEBATES, supra note 93, at xxiv (Rep. Dawes), xxvii (Ohio Sen. and former Ohio Chief Justice Allen Thurman), xxix (Rep. Roger Q. Mills of Texas), xxiii (Rep. Maynard of Tennessee); Avins, supra note 16, at 8-9 (Thurman, Mills, Sen. John Sherman, Ohio Rep. and former Judge William Lawrence, Texas Rep. William Hemdon, and Georgia Sen. Thomas M. Norwood). Crosskey included Ohio Representatives Garfield and Monroe, Massachusetts Representatives Hoar and Benjamin F. Butler, Illinois Representative Farnsworth and Tennessee Representative Horace Maynard. Crosskey, supra note 11, at 93-95. See CONG. GlOBE, 42d Cong., 1st Sess. 499 (Apr. 5, 1871).

136. ROBERT KACZOROWSKI, THE POLITICS OF INTERPRETATION: THE FEDERAL COURTS, DEPARTMENT OF JUSTICE AND CIVIL RIGHTS, 1866-1876, at 57 (1985). When discussing one bill to enforce the Fourteenth Amendment in 1871, Representative M.H. Dunnell said that "[i]t was supposed the fourteenth amendment made doubly certain all the rights set forth in the Constitution." CONG. GLOBE, 42d Cong., Ist Sess., app. at 262 (Apr. 4, 1871).

137. CONG. ReC., 43d Cong., 1st Sess. 342-43 (Dec. 19, 1873).

138. ERIC FONER, RECONSTRUCTION 533 (1988).

139. CONG. GLOBE, 39th Cong., 1st Sess. 566 (Feb. 1, 1866) (emphasis added).

140. Bingham's conviction that an express enforcement provision was required proved correct in $E x$ Parte Virginia, where the Court stated, "Were it not for the fifth section of the Fourteenth Amendment, there might be room for argument that the first section is only declaratory of the moral duty of the State, as was said in Commonwealth of Kentucky v. Dennison." 100 U.S. 339, 347 (1879). 
Senator Henry Wilson agreed with Bingham's overall constitutional analysis in an address on the floor of the Senate, referring to Bingham's March 31,1871 , speech treating the purpose of the Fourteenth Amendments Privileges or Immunities Clause. Wilson said, "I concur entirely in the construction put upon that provision of the fourteenth amendment by Mr. BINGHAM, of Ohio, by whom it was drawn."141

Fairman himself referred to several members of Congress whose comments during the debates on the Fourteenth Amendment were entirely consistent with Bingham's constitutional views. Fairman included the remarks of Frederick E. Woodbridge of Vermont, who indicated that the proposed amendment would protect citizens of the United States in their privileges and immunities guaranteed under the Constitution. Woodbridge said these included the inalienable rights of life and liberty and the protection of property in foreign states. $^{142}$ This statement bears striking resemblance to Bingham's 1862 speech indicating that Fifth Amendment protections were " $[t]$ he great privilege and immunity" of U.S. citizenship. ${ }^{143}$

Fairman quoted from speeches by Congressman William Higby of California, ${ }^{144}$ Congressman William D. Kelley of Pennsylvania, ${ }^{145}$ and Senator Luke E. Poland of Vermont ${ }^{146}$ which included statements that the Fourteenth Amendment would provide enforcement power for existing provisions of the Constitution. Yet Fairman failed to acknowledge that these statements coincided with Bingham's compact theory.

Fairman's assessment of Senator Poland helps explain his failure to place Bingham's constitutional theory within the political and legal mainstream. As Fairman noted, Poland stated that Section One of the Fourteenth Amendment "secure[d] nothing beyond what was intended" by the Privileges and Immunities Clause in Article IV. ${ }^{147}$ A reasonable interpretation of this statement is that Poland meant Section One would "secure" through the Amendment's enforcement provision what the original framers had "intended," but had not "secured" in Article IV, Section 2. This interpretation of Poland's statement is consistent with Bingham's compact and enforcement theories and

141. CONG. GLOBE, $42 \mathrm{~d}$ Cong., 1st Sess. app. at 256 (Apr. 13, 1871).

142. FAIRMAN, RECONSTRUCTION I, supra note 5, at 1279.

143. CONG. GLOBE, 37th Cong., 2d Sess. 1639 (Apr. 11, 1862).

144. According to Higby, an early version of the Fourteenth Amendment would "only have the effect to give vitality and life to portions of the Constitution that ... have been entirely ignored and have become as dead matter in that instrument." FAIRMAN, RECONSTRUCTION I, supra note 5, at 1276. This portion of Higby's speech was reported in The Joint Resolution To Amend the Constitution, N.Y. TIMES, Feb. 28, 1866 , at 1. Higby said that Article IV, Section 2 had been "trampled under foot" and considered "nugatory" in some states. CONG. GLOBE, 39th Cong., 1st Sess. 1054 (Feb. 27, 1866).

145. According to Kelley, "all the power this amendment will give is already in the Constitution. I admit that it has lain dormant." FAIRMAN, RECONSTRUCTION I, supra note 5, at 1276.

146. Id. at 1296.

147. Id. 
finds support in Poland's own language. Poland stated, "Congress should be invested with the power to enforce this provision throughout the country." 148

Fairman, however, ignored this interpretation and the parallel between the views of Bingham and Poland. Instead, Fairman suggested that Poland either spoke imprecisely or simply meant that "the new privileges and immunities clause would mean no more than the old." 149 If the latter interpretation were correct, Fairman implied, the Privileges or Immunities Clause of the Fourteenth Amendment was redundant and its proposal in Congress and Poland's action in supporting it nonsensical. Fairman stated, "Once again, as so often in studying the work of the 39th Congress, one is at a loss to know what the speaker really had in mind." "50 Yet a sensible and logical interpretation of Poland's remarks was available. It is only because Fairman failed to read statements in context that remarks by "respected lawyers" like Poland become unintelligible.

Excerpts from the popular press demonstrate further that Bingham's constitutional views were widely shared. ${ }^{151}$ The National Intelligencer, which Fairman identified as both Washington, D.C.'s leading newspaper and a supporter of President Johnson, espoused Bingham's compact and enforcement theories. It stated, "[Section One] . . . is only, if we understand it correctly, undertaking to carry out what the Constitution now commands."152

An 1871 article in the Nation set forth a Fourteenth Amendment theory which, in large part, echoed all four components of Bingham's constitutional theory. ${ }^{153}$ The Nation explained that the new amendment was "declaratory" and "introduced no new principle." It simply made explicit what the Constitution already implicitly provided: the states were prohibited from making or enforcing any law that would abridge the privileges or immunities of citizens of the United States. ${ }^{154}$ Section One of the Fourteenth Amendment removed any "doubts" regarding this prohibition and "simply put into a

148. Id.

149. Id.

150. Id.

151. Fairman viewed as significant the fact that many newspaper accounts of the Fourteenth Amendment debates focused almost exclusively on Sections Two and Three and that those which did discuss Section One often did not indicate that the new Amendment would apply the Bill of Rights to the states. For instance, Fairman noted the omission of any discussion of the Bill of Rights in the New York Times' May 25, 1866, coverage of Senator Howard's speech introducing the Fourteenth Amendment before the Senate. As Michael K. Curtis has noted, however, the Times had previously reported a speech by Bingham regarding an early version of the Fourteenth Amendment indicating that it would enforce the Bill of Rights against the states. Moreover, Curtis found that the front page of the May 24, 1866, issue of the Times reported Howard's speech, including his indication that the provisions of the Bill of Rights were privileges or immunities under the Fourteenth Amendment. See Faiman, supra note 1, at 68-81; see also CURTIS, supra note 24, at 128 (citing N.Y. TiMES, Mar. 1, 1866, at 5; Mar. 2, 1866, at 2; and May 24, 1866, at 1); Fairman, supra note 1 , at 79 n.146. 1868).

152. FAIRMAN, RECONSTRUCTION I, supra note 5, at 1290 (citing The National Intelligencer, May 15,

153. Rights of Citizens, NATION, May 18, 1871, at 335-36.

154. Id. at 335. 
positive and express form what was before inferential." ${ }^{\text {"5s }}$ The Nation, however, viewed the scope of congressional enforcement power under the Fourteenth Amendment more narrowly than did Bingham. ${ }^{156}$

Rather than promoting an eccentric view of the Constitution, Bingham articulated a theory consistent with the views of many contemporary leading political leaders and journalists. While this accord does not indicate that Bingham's views met with universal approval, it does demonstrate that they were not "singular."

\section{Legal Theorists}

Fairman asserted that Bingham's constitutional theory was idiosyncratic. In fact, Bingham's understanding of the Fourteenth Amendment fell within the mainstream of legal thought during the critical 1866 to 1868 period. At least four legal writers published constitutional law treatises in 1867 and 1868, during and shortly after the ratification process. ${ }^{157}$ Three of these treatises explicitly support Bingham's theory of the Fourteenth Amendment, and the fourth is silent on the point.

\section{Judge Farrar}

In 1867, after the Fourteenth Amendment was proposed but before it was ratified, Judge Timothy Farrar published his Manual of the Constitution of the United States. ${ }^{158}$ In this treatise, Farrar set forth a constitutional theory

155. Id.

156. The Nation argued that Congress could use its enforcement power to remedy the enforcement of a state statute that violated the Fourteenth Amendment, but that the Amendment provided no authority for Congress to remedy the maladministration of otherwise proper state laws. Rather, the Nation argued, the ballot box and public opinion provided the only remedies for these violations. Id.

157. The authors discussed in this Section quite possibly are the only legal scholars who published legal treatises of the Fourteenth Amendment contemporaneously with its ratification. I found no source that purports to compile all the constitutional law treatises from this period. Fairman cited Cooley in his 1949 article, Fairman, supra note 1, at 116 n.306, and Farrar in 1971, FAIRMAN, RECONSTRUCTION I, supra note 5, at 1129-34. Pomeroy has long been known to historians of Reconstruction. Harold M. Hyman, Reconstruction and Political-Constitutional Institutions: The Popular Expression, in 1 NEW FRONTIERS OF THE AMERICAN RECONSTRUCTION 37 (Harold M. Hyman ed., 1966) [hereinafter NEW FRONTIERS]. Several letters led me to Paschal's treatise. See Letter from George W. Paschal to R.B. Hayes (Jan. 16, 1869) (on file in Hayes Presidential Center, Fremont, Ohio); Letter from John A. Bingham to R.B. Hayes (Jan. 14, 1869) (on file in Hayes Presidential Center, Fremont, Ohio).

Sources cited in the treatises by these writers, the traditional literature on the Fourteenth Amendment and Reconstruction, the NINETEENTH-CENTURY LEGAL TREATISES, GUIDE TO THE MICROFICHE COLLECTION (Research Publications, 1984), and the table of cases and authorities provided in THE RECONSTRUCTION AMENDMENTS' DEBATES, supra note 93, at 754-56, suggest no additional constitutional law treatises of relevance published during the 1866-1868 period. For example, George Comstock's four-volume edition of Kent's commentaries was published in 1867, but does not refer to the Fourteenth Amendment. The copy of the Constitution reproduced in the appendix contains only twelve amendments. GEORGE COMSTOCK, 1 COMMENTARIES ON AMERICAN LAW BY JAMES KENT (11th ed. 1867).

158. TIMOTHY FARRAR, MANUAL OF THE CONSTITUTION OF THE UNITED STATES (1867) [hereinafter FARRAR 1867]. Farrar had been Daniel Webster's law partner from 1813 to 1816. See 2 APPLETON'S 
consistent with Bingham's national citizenship and Bill of Rights theories. Like Bingham, Farrar thought that privileges and immunities of Article IV were those of "every citizen of the United States." Ang And like Bingham, Farrar believed that a citizen's privileges and immunities included the provisions of the Bill of Rights. Farrar wrote:

The right of every person to "life, liberty, and property," to "keep and bear arms," to the "writ of habeas corpus," to "trial by jury," and divers others, are recognized by, and held under, the Constitution of the United States, and cannot be infringed by individuals or States, or even by the government itself. ${ }^{160}$

Farrar acknowledged Barron and other contrary authority, but relied on the opinions of New York State Chief Justice Spencer in People v. Goodwin ${ }^{161}$ and Justice Johnson in Houston v. Moor ${ }^{162}$ to argue that the Fifth Amendment applied to both state and national governments. ${ }^{163} \mathrm{He}$ listed the rights of citizens applicable to both governments, paraphrasing and citing all of the first ten amendments. ${ }^{164}$

Thus, like Bingham, Farrar believed that Article IV, Section 2 had already made the Bill of Rights applicable to the states. Farrar wrote, "The clause itself, however, supplies no means for its own execution, and directly invokes no legislative aid from Congress. For more than three quarters of a century, without any legislation or governmental action of any sort, it stood a perfect dead letter in the Constitution." ${ }^{165}$

Unlike Bingham, however, Farrar believed that, even prior to ratification of the Fourteenth Amendment, Congress had had the authority to enact legislation enforcing Article IV. Farrar viewed the Civil Rights Act of 1866 as such an effort. ${ }^{166}$ Still, Farrar fully agreed with Bingham's enforcement theory concerning the purpose and effect of the Fourteenth Amendment. In the 1872 edition of his treatise, Farrar again noted judicial precedents that had held the Bill of Rights inapplicable against the States, but, under the title "Settled

CYClopedia OF AMERICAN BIOGRAPHY 420 (James G. Wilson \& John Fiske eds., 1888). Farrar's father had served as a justice of the New Hampshire Supreme Court and Farrar himself was a judge of the New Hampshire Court of Common Pleas from 1824 to 1826. Id. Judge Farrar was also an abolitionist. See HYMAN \& WIECEK, supra note 102, at 234.

159. FARRAR 1867, supra note 158 , at 199.

160. Id. at 145. Farrar believed that the rights secured by the Bill of Rights were "natural and civil common-law rights" that could not be infringed by "any subordinate government." Id. at 58-59.

161. 18 Johns. 187 (N.Y. 1820).

162. 18 U.S. (5 Wheat) 1 (1820).

163. FARRAR 1867 , supra note 158 , at $395-96$.

164. Id. at 396-97.

165. Id. at 199-200.

166. Id. at 200-02. 
Questions" concluded, "All these decisions ... are entirely swept away by the 14th amendment." 167

Farrar was a respected figure, and his views were widely known. An Ohio congressman, Judge William Lawrence, cited Farrar's 1867 treatise as authority to defend the constitutionality of the 1866 Civil Rights Act. ${ }^{168}$ Historians have praised Farrar's abilities and noted his influence on national leaders during the Civil War and Reconstruction as well as his role "help[ing] to define clearly public attitudes on the nature and purpose of the Constitution." 169

Fairman did not mention Farrar in his 1949 article. In 1971, Fairman cited Farrar's work as an example of "what distortion can be practiced through a zeal to redress injustice."170 Devoting only five pages to Farrar, Fairman focused on and disparaged Farrar's arguments that the Constitution had prohibited slavery from the outset. According to Fairman, Farrar himself was willing to deny "the plain meaning of the Constitution as it had been known from the beginning." 171

Admittedly Farrar's belief in slavery's unconstitutionality was an extreme variant of abolitionist legal theory. Still, a group of legal thinkers, including Lysander Spooner, had advanced this theory as early as $1845 .{ }^{172}$ More significantly, Fairman discussed Farrar's views on slavery while omitting any meaningful reference to Farrar's other constitutional theories. Fairman disagreed with Farrar's views on the Fourteenth Amendment and might have used Farrar's views on slavery to cast doubt on Farrar's judgment that the Fourteenth Amendment was designed to overrule Barron and to enforce the Bill of Rights against the States. Instead, Fairman ignored entirely Farrar's view that the Fourteenth Amendment applied the Bill of Rights to the states, a view contrary to Fairman's own.

\section{Judge Paschal}

Judge George W. Paschal's The Constitution of the United States Defined and Carefully Annotated, ${ }^{173}$ published in 1868, further supports the argument

167. Timothy FarRaR, MANUAL of the CONSTtTUTION OF THE UNITED STATES 546 (3d ed. 1872) [hereinafter FARRAR 1872]. While Farrar did not explicitly cite any cases, he was undoubtedly referring to Barron v. Baltimore, 32 U.S. (7 Pet.) 248 (1833), and its progeny.

168. ConG. GloBE, 43d Cong., 1st Sess. 413 (January 6, 1874); see also Cong. GloBE, 41 st Cong., 3d Sess. 1244 (Feb. 14, 1871) (on the Guarantee Clause).

169. Hyman, supra note 157, at 30-32; see also CARL B. SWISHER, THE TANEY PERIOD, 1836-1864, at 643, in 5 History OF THE SUPREME COURT OF THE UNITED STATES (Paul A. Freund, ed., 1974) (calling Farrar an "able Boston lawyer"); Samuel Lee, Timothy Farrar, LL.D., 29 NEw ENG. HIST. \& GENEALOGICAL REG. 21 (1875).

170. FAIRMAAN, RECONSTRUCTION I, supra note 5, at 1129.

171. Id. at 1134.

172. See ROBERT M. COVER, JUSTICE ACCUSED 156-58 (1975).

173. GeoRge W. PASCHAL, THE CONSTITUTION OF THE UNITED STATES (1868) [hereinafter PASChaL 1868]. 
that Bingham's constitutional theory fell within the legal mainstream. Paschal was a prominent politician, lawyer, jurist, and law professor. ${ }^{174}$ Paschal published his treatise while the ratification of the Fourteenth Amendment was pending. ${ }^{175} \mathrm{He}$ called on his readers to consider "carefully" the effect of the Amendment, and then he proposed to explain that effect. ${ }^{176}$ Paschal cited Farrar's interpretation of the Fourteenth Amendment with approval. ${ }^{177}$ Paschal viewed the citizenship clause of Section One of the Fourteenth Amendment as constitutionalizing Section One of the Civil Rights Act. ${ }^{178}$ Of the remainder of Section One of the Fourteenth Amendment, he wrote:

\begin{abstract}
All else in this section has already been guaranteed in the second and fourth section of the fourth article; and in the thirteen amendments. The new feature declared is that the general principles which had been construed to apply only to the national government, are thus imposed upon the States. Most of the States, in general terms, had adopted the same bill of rights in their own constitutions. ${ }^{179}$
\end{abstract}

Thus, Paschal echoed Bingham's view that the Fourteenth Amendment would enforce the Bill of Rights against the states. By indicating that "most" states had adopted the same bill of rights in state constitutions, Paschal also addressed and defused the argument later espoused by Fairman that inconsistencies between the federal Bill of Rights and the rights provided in various state constitutions were fatal to Bingham's enforcement theory. ${ }^{180}$

174. Paschal studied law in Georgia, served as a justice on the Arkansas Supreme Court, and was active in law and politics in Texas. 4 APPLETON's ENCYCLOPEDIA OF AMERICAN BIOGRAPHY, supra note 158, at 667. He was influential in the election of Unionist candidate Samuel Houston as Governor of Texas in 1859 , id., and his support for the Union later led to his arrest for disloyalty to Texas. See id.; Jane L. Scarborough, George W. Paschal, Texas Unionist and Scalawag Jurisprudent, 76 (1972) (unpublished Ph.D. dissertation, Rice University). Paschal moved to Washington, D.C., in 1869 and helped found the law department of Georgetown University, where he became first professor of jurisprudence. Id. at 76. In a public speech in 1870, Paschal indicated that he had given much of his life to the study of "the true principles of the Constitution." George W. PASChal, LeCtuRE DELIVERED to THE AMERICAN UNION

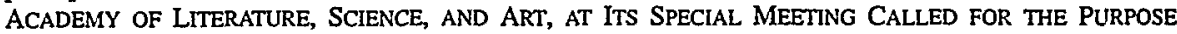
(MARCH 7, 1870), reprinted in GEORGE H. PASCHAL, The CONSTTtuTtON OF THE UNITED STATES, DEFINED AND CAREFully ANNOTATED, at xliv (2d ed. 1876) [hereinafter PASCHAL 1876].

175. PASCHAL 1868 , supra note 173 , at $280-81$.

176. Id. at 290.

177. Id. at 281 (referring to Farrar as one whose opinions are "entitled to respect" on question of ratification of Fourteenth Amendment), 290 (on the effect of the citizenship clause), 293 (giving a "see" reference to Farrar's discussions of Sections One and Two of the Amendment).

178. Id. at 290.

179. Id. (emphasis added). In an 1870 speech, Paschal listed actions that were prohibited to both the federal government and the states. These included:

establishing religion, or preventing the free exercise thereof; abridging the freedom of speech, of the press, or the right of petition; instituting domiciliary visits; abolishing grand juries and jury trial for the citizen not connected with the military service; invading life, liberty, or property without due process of law, or in any manner violating the most enlarged principles of republican government.

PASCHAL, LECTURE, reprinted in PASCHAL 1876, supra note 174, at xli.

180. Fairman, supra note 1 , at 84-128. 
Unlike Bingham, however, Paschal did not believe that Article IV, Section Two had applied the Bill of Rights to the states prior to the Fourteenth Amendment. Nevertheless, Paschal agreed with Bingham regarding what the Fourteenth Amendment accomplished. ${ }^{181}$

Not surprisingly, Bingham endorsed Paschal's treatise. In a January 14, 1869 , letter to Ohio Governor Rutherford B. Hayes, Bingham indicated that he considered Paschal's book to be "a want by the whole country."182 Bingham encouraged Hayes to purchase copies of the book for members of the state legislature because "it is well to give public officials the means of more fully understanding [the Constitution's] sure and essential provisions." 183 Four years later, as Chairman of the House Judiciary Committee, Bingham asked the House of Representatives to purchase ten thousand copies of Paschal's book for distribution to members of the House. Though Bingham's praise for the book focused on its treatment of Supreme Court cases, he noted that "it is an aid really to every Representative in Congress." ${ }^{.184}$ Following his appointment as minister to Japan, Bingham indicated that he wanted Paschal's treatise included with the books for the Japanese Legation. ${ }^{185}$

Bingham was but one of many national leaders impressed with Paschal's work. Representative William Lawrence, ${ }^{186}$ Senator George Vickers, ${ }^{187}$ Representative James Garfield, ${ }^{188}$ and Senator Lyman Trumbull ${ }^{189}$ relied on Paschal's 1868 treatise during speeches on the floor of Congress. The Constitutional Convention of Texas and some state legislatures purchased copies. ${ }^{190}$

Justice Samuel Miller referred to the treatise as a "very valuable work." ${ }^{\prime 19}$ Former Representative Albert Riddle, a Washington lawyer and law professor at the Howard University Law Department, praised the treatise as "the most convenient and useful, the most extensive and valuable digest of

181. See PASCHAL 1868, supra note 173 , at 225-65.

182. Letter from John A. Bingham to Rutherford B. Hayes (Jan. 14, 1869) (on file in the Hayes Presidential Center, Fremont, Ohio).

183. Id. In a letter dated January 27, 1869, W.R. Thrall, the Private Secretary to Governor Hayes, replied to a letter of Judge Paschal dated January 16, 1869. Mr. Thrall indicated that Paschal's book was "commended generally" by many members of the state legislature, but that they had no "disposition" to order copies for their use. Letter from W.R. Thrall to George W. Paschal (Jan. 27, 1869) (on file in the Hayes Presidential Center, Fremont, Ohio).

184. CONG. GloBE, 42d Cong., 3d Sess. 858 (Jan. 25, 1873). While Congressmen Garfield and Farnsworth successfully opposed Bingham's motion, they both praised the treatise. Id.

185. John A. Bingham, List of Books for the Japanese Legation (July 1873) (on file in the Bingham Papers, Milton Ronsheim Collection, Cadiz, Ohio).

186. CONG. GloBE, 41st Cong., 3d Sess. 1243-45 (Feb. 14, 1871).

187. CONG. GLOBE, 42 d Cong., 2d Sess. app. at 41 (Feb. 8,1872 ).

188. CONG. GLOBE, 42d Cong., 1st Sess. app. at 152 (Apr. 4, 1871) ("I hold in my hand Paschal's annotated edition of the Constitution.").

189. CONG. GLOBE, 42d Cong., Ist Sess. 575 (Apr. 11, 1871).

190. Letter from George W. Paschal to Rutherford B. Hayes (Jan. 16, 1869) (on file in the Hayes Presidential Center, Fremont, Ohio); see also HAROLd M. HyMAN, A MoRe Perfect UNION 517 (1973) (describing Paschal's treatise as "an important addition to nationalist constitutionalism")

191. Justice Samuel Miller, The Constitution of the United States 34 (1880). 
these precedents we have."192 Speaking of Paschal, Riddle concluded that Paschal "accurately apprehended the Constitution in all its aspects."193

Paschal's treatise and the praise for it suggest that people who disagreed with Bingham on many political issues nevertheless shared his view concerning the purpose of the Fourteenth Amendment. While Farrar and Bingham both opposed slavery, Paschal was no abolitionist. Paschal was originally a Jacksonian Democrat and a slaveholder. ${ }^{194}$ Shortly after the Civil War, Paschal said that he had supported "every measure which extended the area of slavery" and that he had believed it "was religiously, morally and economically right, wise and just." 195 He criticized Northerners who moved to the South after the war, supported pardons for Confederate leaders such as Vice President Alexander H. Stephens and Postmaster General John H. Reagan, and publicly denigrated the character and abilities of African Americans. ${ }^{196}$ Paschal nevertheless "worked diligently for the adoption of the Fourteenth Amendment."197 Indeed, Paschal's statements indicating that the Fourteenth Amendment made the Bill of Rights applicable to the states suggests that that proposition was far less exceptionable than Fairman implied.

Fairman was aware of Paschal's prominence, but did not consider Paschal's treatise when evaluating the Fourteenth Amendment. Fairman included Paschal in a list of the "leading practitioners" of the Supreme Court in $1873 .{ }^{198} \mathrm{He}$ described Paschal as "a leading Texas lawyer and steadfast Unionist"199 and gave him credit for having played a "large part" in winning Texas v. White. ${ }^{200}$ Though Fairman had cited Paschal's treatise in his 1939 biography of Justice Miller, ${ }^{201}$ he made no reference to it in his 1949,1971 ,

192. IN MEMORIAM-HON. GEO. W. PASChal 9 (undated pamphlet on file in the Library of Congress); see also James P. Hart, George W. Paschal, 28 TEX. L. REV. 23, 42 n.84 (1949).

193. IN MEMORIAM-HON. GEO. W. PASCHAL, supra note 192, at 9.

194. Scarborough, supra note 174 , at ii, 11,143 . In 1870 , even while indicating he would not defend slavery, Paschal argued that it had been "humanized" in the United States. Paschal, Lecture, in PASCHAL 1876, supra note 174 , at xxvi.

195. JAMES MARTEN, TEXAS Divided 72 (1990). Paschal was "radically opposed to . . Free Soilism, Black Republicanism, and the abolition of slavery." 7 THE WRITINGS OF SAM HOUSTON $340 \mathrm{n} .1$ (Amelia W. Williams \& Eugene L. Barker eds., 1942).

196. Hart, supra note 192 , at $23,30-31$.

197. THE WRITINGS OF SAM HOUSTON, supra note 195, at 340 n.l.

198. FAIRMAN, RECONSTRUCTION II, supra note 5, at 3-4.

199. FAIRMAN, RECONSTRUCTION I, supra note 5, at 632. Born in Georgia of Southern parents, Paschal indicated that his father was "ardently devoted to the Union," GEORGE W. PASCHAL, NINETY-FOUR YeARS-AGNeS PASCHAL 196 (Reprint. Co., Spartanburg, S.C. 1974) (1871), and that when the Civil War came "[i]t found Mrs. Agnes Paschal true to the Union," id. at 300. Paschal himself was described as "a loyal citizen of the State of Texas." Texas v. Hardenberg, 77 U.S. (10 Wall.) 68, 70 (1869).

200. Texas v. White, 74 U.S. (7 Wall.) 700 (1868), was a complex and bitterly fought case in which the reconstruction government of Texas invoked the original jurisdiction of the Supreme Court to recover state-owned securities sold by the pro-Confederate state government. In the course of vindicating the claim of the reconstruction government, the Court held that the Union was indestructible and perpetual, but that only Congress had the authority to reestablish legal relations between the state government and the national government.

201. FAIRMAN, supra note 44, at 351 n.24. 
or 1987 Fourteenth Amendment writings. ${ }^{202}$ Had he dealt with this treatise, Fairman would have found that its views on incorporation were identical to Bingham's.

\section{Dean Pomeroy}

Shortly after the Fourteenth Amendment had been proposed, John Norton Pomeroy authored a treatise entitled An Introduction to the Constitutional Law of the United States. At the time, Pomeroy was Dean of the Law School and Griswold Professor of Political Science at the University of New York. ${ }^{203}$

In this treatise, Pomeroy described the provisions of the first eight amendments as "the immunities and privileges guarded by the Bill of Rights." ${ }^{204} \mathrm{He}$ suggested that the generality of the language used in the first eight amendments could be read to indicate the amendments applied to the states as well as to the national government. ${ }^{205}$ Pomeroy recognized that Barron v. Baltimore ${ }^{206}$ and state cases following it held the first eight amendments applied only to the federal government. ${ }^{207} \mathrm{He}$ declared this result "an unfortunate one" ${ }^{208}$ which called for a remedy. ${ }^{209}$ According to Pomeroy "[s]uch a remedy is easy, and the question of its adoption is now pending before the people."210 Citing the portion of the Fourteenth Amendment drafted by Bingham-all of Section One but the Citizenship Clause-Pomeroy considered this provision "by far more important" than any other amendment except the Thirteenth Amendment. ${ }^{211}$ Echoing Bingham's views that the Amendment infringed on no right of the states, Pomeroy wrote:

202. See Fairman, supra note 1; FAIRMAN, RECONSTRUCTION I, supra note 5; FAIRMAN, RECONSTRUCTION II, supra note 5.

203. JOHN N. POMEROY, AN INTRODUCTION TO THE CONSTTTUTIONAL LAW OF THE UNITED STATES, at i (1868) [hereinafter POMEROY 1868]. For an account of Pomeroy's prominence, see Stephen A. Siegel, Historicism in Late Nineteenth-Century Constitutional Thought, 1990 WIS. L. REV. 1431, 1453-54.

204. POMEROY 1868, supra note 203, at 147; see also Hawaii v. Mankichi, 190 U.S. 197, 217-18 (1903) ("... the privileges and immunities contained in the Bill of Rights"); JOHN W. BURGESS, 1 POLITICAL SCIENCE AND COMPARATIVE CONSTITUTIONAL LAW 184 (1891) (describing Bill of Rights as " $\mathrm{a}$ bill of immunities"); Charles R. Pence, The Construction of the Fourteenth Amendment, 25 AM. L. REV. 536,540 (1891) (noting that first eight amendments confer privileges and immunities).

205. POMEROY 1868 , supra note 203 , at 145 . Pomeroy regarded this point as largely theoretical since he thought state governments had provisions that duplicated the federal Bill of Rights. Id. at 145-46. Fairman later argued that several states did not have a grand jury requirement and would not have ratified the Fourteenth Amendment if it had been intended to apply the Bill of Rights to the states. Fairman, supra note 1 , at 82-132. Pomeroy apparently was unaware of such differences between state and federal practice and argued that if the federal Bill of Rights did not apply to the states, then the states could do what some had indeed done: abolish, among other protections, the grand jury. POMEROY 1868, supra note 240, at 146.

206. 32 U.S. (7 Pet.) 243 (1833).

207. POMEROY 1868, supra note 203, at 147, 149.

208. Id. at 149 .

209. Id. at 151 .

210. Id.

211. Id. 
[The Fourteenth Amendment] would give the nation complete power to protect its citizens against local injustice and oppression; a power which it does not now adequately possess, but which, beyond all doubt, should be conferred upon it. Nor would this amendment interfere with any of the rights, privileges, and functions which properly belong to the individual states. ${ }^{212}$

Pomeroy's publications, like those of Farrar and Paschal, were known nationally. ${ }^{213}$ Secretary of State Elihu Root, a student of Pomeroy's, remembered him as possessing "broad and accurate learning and a powerful and discriminating mind, capable of the most accurate analysis, and a strong sense of proportion." 214 Pomeroy was an important Republican theoretician who, like Paschal, has been described as a "state-rights nationalist."21s Mllinois Senator Lyman Trumbull relied on Pomeroy on the issue of voting qualifications in congressional elections. ${ }^{216}$ Furthermore, West Point and various other colleges used his treatise as a textbook. ${ }^{217}$

In a contemporary review of Pomeroy's volume, the Nation praised it as a "statesmanlike" investigation of the Constitution and labelled the author "so impartial a writer."218 The Nation endorsed Pomeroy's view that the Bill of Rights was not as yet enforceable against the states and, consequently, argued that the pending Fourteenth Amendment should be adopted. ${ }^{219}$

In 1939, Fairman acknowledged the prominence of Dean Pomeroy ${ }^{220}$ but made no reference to Pomeroy's treatise. References to Pomeroy's view on incorporation of the Bill of Rights are prevalent in the Reconstruction literature and would have been relevant to Fairman's various writings. ${ }^{221}$ By 1987 , when

212. Id.

213. Phillip S. Paludan, A Covenant With Death 219 (1975).

214. John N. Pomeroy, Jr., John Norton Pomeroy, 1828-1885, in 8 Great AMERICAN LAWYERS 101 (William D. Lewis ed., 1909).

215. HYMAN \& WIECEK, supra note 102 , at 409.

216. Cong. Globe, 41st Cong., 2d Sess. 1363 (Feb. 17, 1870) ("I read from Pomeroy's Constitutional Law, a recent and valuable work.").

217. 5 APPLETON'S CYCLOPEDIA OF AMERICAN BIOGRAPHY, supra note 158, at 60.

218. Pomeroy's Constitutional Law, NATION, July 16, 1868, at 53, 54.

219. Id. at 54. Three years later, in an editorial opposing the Force Bill of 1871 , the Nation looked at the intent behind the Fourteenth Amendment. The unsigned article stated:

The comprehensive bill of rights contained in the first eight amendments applied to the action of Congress alone, and did not control that of the States .... This was a great evil, and there was danger lest it might become greater. To remedy it, the Fourteenth Amendment was adopted. This was the sole design of that most just and beneficial change.

The Force Bill, NATION, Apr. 20, 1871, at 268, 270. Although the article was not signed, Howard J. Graham claimed that Dean Pomeroy had written it. Howard J. Graham, Our "Declaratory" Fourteenth Amendment, 7 STAN. L. REV. 3, 28 n.120 (1954).

220. FAIRMAN, supra note 44, at 297-98 (discussing Pomeroy's work on Justice Field's presidential efforts).

221. See, e.g., Hyman, supra note 157, at 35. In particular, Pomeroy's views on incorporation would have been relevant to Fairman's discussion in his second volume of Reconstruction and Reunion of one of the first federal cases to interpret the Fourteenth Amendment as enforcing the Bill of Rights against the states. FAIRMAN, RECONSTRUCTION II, supra note 5, at 188-93 (discussing United States v. Hall, 26 F. Cas. 79 (S.D. Ala. 1871) (No. 15,282)). 
Fairman published his second volume of Reconstruction and Reunion, Harold Hyman and William Wiecek, ${ }^{222}$ Robert Kaczorowski, ${ }^{223}$ and Michael Kent Curtis had all discussed Pomeroy's relevance to the debate. ${ }^{224}$ Yet, Fairman's analysis demonstrates no awareness of Pomeroy's views, their indication that Bingham's views were not eccentric, nor their impact on the way people in 1868 viewed the Fourteenth Amendment.

\section{Justice Cooley}

In his Fourteenth Amendment writings, Fairman made only cursory reference to the writings of Farrar, and none to the publications of Paschal and Pomeroy. He relied primarily on a fourth scholar, Justice Thomas Cooley, to support his claim that Bingham's contemporaries did not believe the Fourteenth Amendment made the first eight amendments directly applicable to, and enforceable against, the states. An evaluation of Justice Cooley's writings, however, reveals that Cooley's positions-which varied over time-do not provide contemporary support for Fairman's argument. In 1868, Cooley published a constitutional law treatise in which he did not address the Fourteenth Amendment at all. Three years later, his comments in a revised edition of the treatise concerning the Amendment can be read to support Bingham's interpretation of the Amendment's purpose. Only in 1873 and 1874 did Cooley reject that position after a misreading of Article IV, Section Two and the text of the Amendment.

In his 1949 article, Fairman noted the "absence" of any reference to the application of the Bill of Rights against the states in the first three editions of Justice Cooley's Constitutional Limitations, ${ }^{225}$ implying that Cooley had discussed the Fourteenth Amendment without referring to the Bill of Rights. In fact, Justice Cooley made no reference at all to the Fourteenth Amendment in his 1868 edition. ${ }^{226}$ Although published in September, after both Congress and the Secretary of State declared the Fourteenth Amendment ratified, ${ }^{227}$ Cooley never discussed the new Amendment. Thus, Cooley's view, at the time of ratification, of the purpose of the Fourteenth Amendment is not available.

Cooley published his second edition of Constitutional Limitations in 1871. This edition includes two statements which can be interpreted to suggest that the Fourteenth Amendment applied the Bill of Rights to the states. After

222. HYMAN \& WIECEK, supra note 102, at 409.

223. Robert J. Kaczorowski, Revolutionary Constitutionalism in the Era of the Civil War and Reconstruction, 61 N.Y.U. L. REV. 863, 932 n.349 (1986).

224. CuRTIS, supra note 24 , at $172-73$.

225. Fairman, supra note 1 , at 116 n.306.

226. ThOMAS COOLEy, CONSTITUTIONAL LimitaTions (1868) [hereinafter CoOley 1868]. Fairman cites no specific pages in his reference to the first edition of Constitutional Limitations. Fairman, supra note 1 , at 116 n.306.

227. Faiman, supra note 1, at chart opposite 134. 
discussing the Citizenship Clause, Cooley wrote: "[I]t may be doubtful whether the further provisions of the same section surround the citizen with any protections additional to those before possessed under the State Constitutions; but . . . a principle of State constitutional law has now been made a part of the Constitution of the United States."228 Cooley then stated that he considered it "conceded" that privileges and immunities included the right to "protect and defend" one's property "in the law" and the "enforcement of other personal rights." 229 If Cooley viewed the federal Bill of Rights as protecting the same rights as state constitutions or as offering protections which are characterized as "personal rights,"230 then his 1871 Fourteenth Amendment views contradict Fairman's and coincide with those of Bingham.

A century later, however, Fairman implied that Cooley in fact rejected arguments supporting Bingham's view of the Fourteenth Amendment. Fairman quoted Cooley out of context to suggest that Cooley disagreed with Justice Bradley's opinion in the lower court decision of the Slaughter-House Cases. As a synopsis of Cooley's position, Fairman wrote: "The matter was pending before the Supreme Court and perhaps it was not proper to comment; but if the claim were to be upheld, 'an innovation will be made in our system which ought not to be made without careful consideration and deliberate intention.' Evidently he did not approve." "231 Fairman suggested that Cooley disagreed with the substance of the lower court opinion.

Read in context, however, the object of Justice Cooley's disapproval becomes clear. Cooley objected to federal lower court review of state legislation, believing that task belonged to the Supreme Court alone. Contrary to Fairman's assertion, Cooley did not express any objection to Bradley's view of the Fourteenth Amendment. Cooley wrote:

228. ThOMAS COOLEY, CONSTITUTIONAL Limitations *294 (2d ed. 1871) [hereinafter COOLEY 1871]. This statement may suggest that Cooley, like Pomeroy and Paschal, knew of no conflicts between the Bill of Rights and state constitutional provisions.

229. COOLEY 1871 , supra note 228 , at 397.

230. The view that the federal Bill of Rights protects "personal rights" was widely shared. See COOLEY 1868 , supra note 226 , at 18 ("[P]rohibitions . . . designed for the protection of rights of persons or property are usually repeated in the bills of rights contained in the state constitutions."). In 1849 abolitionist theorist Joel Tiffany referred to the federal Bill of Rights as guarantees for "personal security and liberty." JOEL TIFFANY, A TREATISE ON THE UNCONSTITUTIONALITY OF AMERICAN SLAVERY 99 (1849), quoted in Curtis, supra note 24, at 72. Boyd v. United States, 116 U.S. 616 (1886), also referred to the Fourth and Fifth Amendments as constitutional provisions "for the security of person and property." Id. at 635 , cited in Curtis, The Bill of Rights as a Limitation, supra note 24 , at 72 .

The Freedman's Bureau Bill provided for "full and equal benefit of all law and proceedings for the security of person and estate, including the constitutional right of bearing arms." CONG. GLOBE, 39th Cong., 1st Sess. 654, 743, 1292 (1866), quoted in CuRTIS, supra note 24, at 72.

In an 1856 speech concerning the assault on Senator Charles Sumner and proposed expulsion of Preston Brooks, Bingham stated that the freedom of speech and "security of person" were "great rights which underlie and are essential to all representative Government." CONG. GLOBE, 34th Cong., Ist Sess. 1577 (July 9, 1856). He cited the Fourth Amendment as guaranteeing "security of person." Id. at 1578.

231. FAIRMAN, RECONSTRUCTION I, supra note 5, at 1368 (quoting COOLEY 1871, supra note 228, at $* 574$ n.3). 
State legislation in violation of the fourteenth amendment, or of any other provision of the Constitution, if sustained by the State Court of last resort, may be set aside by the federal Supreme Court on appeal, as provided by the Judiciary Act of 1793; but when general original jurisdiction to supervise or review State legislation shall be conferred upon the federal judiciary, an innovation will be made in our system which ought not to be made without careful consideration and deliberate intention. ${ }^{232}$

Cooley published his third edition of Constitutional Limitations in 1874. In this edition, he cited twice his fourth edition of Story on the Constitution. ${ }^{233}$ In Story, Cooley misparaphrased the Article IV, Section Two's language, "the privileges of citizens in the several States," as "the privileges of citizens of the several States."234 Cooley then distinguished between the privileges and immunities of state citizens and the privileges and immunities of national citizens; he argued that the Fourteenth Amendment only protected a limited number of rights such as international protection, use of navigable waters and use of postal services. Cooley noted that state laws continued to secure most protections of a citizen's privileges and immunities. ${ }^{235}$ Thus, in contrast to Cooley's earlier work, his 1873 and 1874 works support Fairman's analysis rather than Bingham's position. ${ }^{236}$ And it was on this section that Professor Fairman relied for his 1971 volume Reconstruction and Reunion. ${ }^{237}$

Fairman's reliance on Cooley's 1873 and 1874 views is inconsistent with his professed commitment to using contemporary evidence. After all, Fairman rejected Bingham's 1871 speech indicating that the first eight amendments were among the privileges and immunities of United States citizens, ${ }^{238}$ because Bingham gave this speech three years after the passage of the

232. COOLEY 1871 , supra note 228 , at $* 573-74$ n.3 (emphasis added).

233. Thomas M. Cooley, Constitumonal Limitations, $* 12$, *573 n.3 (3d ed. 1874) [hereinafter COOLEY 1874]. STORY].

234. ThOMAS M. COOLEY, 2 StORY ON THE CONSTITUTION 658 (4th ed. 1873) [hereinafter COOLEY,

235. Id. at 658-59.

236. Id. Cooley specifically stated that the constitutional amendments relating to criminal trials applied only to those charged with a crime by the federal government and not to those charged with a crime by the states. Id. at 666.

In Story, Cooley defined life, liberty and property to include "every right to which a member of the body politic is entitled under law." Id. at 668-69. Cooley then proceeded to discuss arbitrary arrests, freedom of speech, and freedom of religion. Cooley's words were so expansive as to cause Robert Kaczorowski to conclude that, in 1873, Cooley acknowledged that the Fourteenth Amendment's Due Process Clause extended the Bill of Rights to the states. ROBERT J. KACZOROWSKI, THE NATIONALIZATION oF CIVIL RIGHTS 289 (1987). Though Cooley's more specific words are a more reliable guide to his views, the passages relied upon by Kaczorowski suggest that Cooley may not have fully considered the implications of all that he said.

237. FAIRMAN, RECONSTRUCTION I, supra note 5, at 1368-69.

238. Cong, GloBe, 42 Cong., 1st Sess. app. at 84 (Mar. 31, 1871). 
Amendment. ${ }^{239}$ Applying Fairman's own standard would mean that Cooley's 1873 and 1874 views should not be used to determine the purpose of the Fourteenth Amendment. ${ }^{240}$

Thus, of four authors writing at the time of the adoption of the Fourteenth Amendment, three articulated a view of the Constitution that supported Bingham's constitution il interpretation and his enforcement theory in particular. A fourth writer, Justice Cooley, contrary to the suggestion of Professor Fairman, did not provide a contemporary view of the Fourteenth Amendment. Among those who discussed the Fourteenth Amendment for the public and the bar, Bingham's views do not appear "singular," as Fairman claimed. To the contrary, contemporaneous legal commentators almost uniformly shared Bingham's conception that the Fourteenth Amendment applied the Bill of Rights to the states.

\section{LOCAL CONFLICTS WITH THE BILL OF RIGHTS}

Fairman's most credible argument that the Fourteenth Amendment did not apply the Bill of Rights to the states rests on the conflict between state law, both constitutional and statutory, and the requirements set forth in the Bill of Rights. ${ }^{241} \mathrm{He}$ suggests that congressmen and state legislators would not have adopted the Fourteenth Amendment had they understood it to conflict with local practices. At the very least, Fairman noted, they would have changed local practices after ratification. ${ }^{242}$ This argument, while facially persuasive, rests on faulty logic.

Bingham and the other members of Congress knew the contents of the provisions of the Bill of Rights. Bingham also knew that he wanted the Bill of Rights "enforced everywhere." ${ }^{.243}$ But he and his contemporaries did not

239. Fairman, supra note 1, at 137 ("[Bingham] had a full opportunity to express his understandings in 1868.").

240. Cooley was not the sole author of constitutional texts during early 1870 's nor were his views universally held. Another treatise, published the same year as the third edition of Cooley's Constitutional Limitations, reached opposite conclusions. See ISRAEL W. ANDREWS, MANUAL OF THE CONSTITUTION (1874). Andrews suggested that Section One of the Fourteenth Amendment was written explicitly to counteract the view that the Bill of Rights did not apply to the states:

And as it has been maintained that the first eight Amendments had no reference to the State governments, but were restraints upon the general government only, this Fourteenth Amendment declares explicitly that 'No State shall make or enforce any law which shall abridge the Id. at 274. privileges or immunities of citizens of the United States.

241. Fairman, supra note 1, at 81-132. Fairman may have based his argument on the majority opinion in Hurtado v. California, 110 U.S. 516, 537 (1883). The Hurtado Court, noting that Connecticut did not require grand juries in capital cases at the time of the ratification of the Fourteenth Amendment, concluded that a grand jury was required only in federal capital cases.

Crosskey suggests that many of these conflicts were more apparent than real. CRosskeY, supra note 11, at 85-90. In his reply, Fairman did not specifically respond to that portion of Crosskey's analysis. Fairman, A Reply to Professor Crosskey, supra note 11, at 144.

242. Fairman, supra note 1 , at 82-84.

243. CONG. GLOBE, 39th Cong., 1st Sess. 1292 (Mar. 8, 1866). 
know the contents of every state statute and constitution. Indeed, Judge Paschal evidenced no knowledge of state constitutional provisions that conflicted with the Bill of Rights. ${ }^{244}$ Yet, Bingham, Farrar, and Paschal all believed that the Bill of Rights already applied to the states and that local officials who enforced local laws in conflict with the Bill of Rights were violating their oaths of office. They believed the Fourteenth Amendment created an enforcement mechanism that would authoritatively resolve any conflict. ${ }^{245}$ They favored the principles of the Bill of Rights over the preservation of unconstitutional local practices. In 1866, Bingham told Congress "that many of the States-I might say, in some sense, all the States of the Union-have flagrantly violated the absolute guarantees of the Constitution of the United States to all its citizens."246

In his last major speech in the House before the vote on the Fourteenth Amendment, Bingham stated that "many of [the states] ha[d] assumed and exercised the power" to violate the privileges and immunities of U.S. citizens. ${ }^{247}$ Four years later, Bingham welcomed the adoption of the Fifteenth Amendment and its enforcement provisions to overcome Ohio's prohibition of voting rights for African Americans. ${ }^{248}$ No evidence suggests that Bingham was less willing for the Fourteenth Amendment to overrule state practices contrary to the Bill of Rights.

Fairman's own research demonstrates the error of his conclusion that conflicts between local provisions and the federal Bill of Rights indicate that the Fourteenth Amendment did not enforce the Bill of Rights against the states. For instance, Fairman noted that Senator Howard, the spokesman for the Fourteenth Amendment in the Senate, had concluded that the Fourteenth Amendment's Privileges or Immunities Clause encompassed the first eight amendments. ${ }^{249}$ Fairman also noted that Howard had been Attorney General of Michigan when the Michigan legislature enacted a statute that allowed criminal cases to be initiated without indictment by the grand jury as required by the Fifth Amendment. ${ }^{250}$ If Howard knew of this conflict, then he likely believed that, if ratified, the Fourteenth Amendment would render the

244. See PASChal 1868, supra note 173 , at 290 . For the possibility that Cooley also thought there were no conflicts, see supra note 228 and accompanying text.

245. Radical Republicans advocated that "all state constitutions [should] accord with the central one." November 26, 1868, Sermon of Rev. Alexander Clark, in The Radical Republicans and RECONSTRUCTION, 1861-1870, supra note 129, at 464. Even if they agreed with Pomeroy, who recognized the legitimacy of state practices contrary to the Fifth, Sixth, and Seventh Amendments, they could nevertheless have taken Pomeroy's position that the Fourteenth Amendment should be adopted to overcome these state practices. POMEROY 1868, supra note 203, at 148-49.

246. CONG. GLOBE, 39th Cong., 1st Sess. 158 (Jan. 9, 1866). 51.

247. CoNG. GloBE, 39th Cong., 1st Sess. 2542 (May 10, 1866), quoted in Fairman, supra note 1, at

248. CONG. Globe, 41 st Cong., 2d Sess. 3503 (May 10, 1870).

249. Fairman, supra note 1, at 57 (referring to, but not citing CoNG. GLOBE, 39th Cong., Ist Sess. 2765 (May 23, 1866)).

250. Fairman, supra note 1 , at 115-16. 
Michigan statute unconstitutional. If, however, he was unaware of the conflict, then its existence cannot have affected his understanding of the Amendment's purpose.

A similar analysis applies to the state legislatures. Fairman pointed out that Bingham specifically identified Oregon as one of the states whose constitution or statutes violated the U.S. Constitution and whose violations could be addressed by one of the early proposed versions of the Fourteenth Amendment. $^{251}$ The offending provision of the Oregon Constitution, which discriminated against African Americans, was not repealed until November 2, 1926. ${ }^{252}$ Nevertheless, Fairman indicated that the Republican majority in the state legislature voted to adopt the Fourteenth Amendment. ${ }^{253}$ The Republican majority did so even though the state constitution violated the Equal Protection Clause-a portion of the Fourteenth Amendment that explicitly applied against the state regardless whether Section One also incorporated the Bill of Rights.

Thus, Fairman's examples do not support his conclusion. Jurists and scholars like Judge Paschal perceived no conflict between state constitutional, on the one hand, and the Bill of Rights on the other. To the extent that such conflicts did exist, the intent of the Fourteenth Amendment was to resolve the conflicts by enforcing the Bill of Rights. Fairman's examples, Senator Howard and the statutory provision of Michigan, in fact indicate that such conflicts provide no assistance in interpreting the Amendment. His Oregon example indicates that even when a specific conflict between the Fourteenth Amendment and a state constitutional provision existed, states nevertheless took the seemingly inconsistent action of ratifying the Amendment and failing to repeal the offending state provision.

\section{INITIAL JUDICIAL INTERPRETATIONS}

Notwithstanding Fairman's assertions to the contrary, Bingham was a respected lawyer and congressman; his reasoning was cogent and consistent; and his view that the Fourteenth Amendment applied the Bill of Rights to the states was widely shared by contemporary politicians and legal scholars. An analysis of the initial judicial interpretations concerning the Fourteenth Amendment reveals that several judges also believed that the Fourteenth Amendment applied the Bill of Rights against the states. This Section will

251. Fairman, supra note 1, at 31-32 (citing CONG. GLOBE, 39th Cong., 1st Sess. 1065 (1865) and quoting Bingham's statement that the Fourteenth Amendment "is to apply to other States also that have in their constitutions and laws to-day provisions in direct violation of every principle of our Constitution. ... . It applies unquestionably to the State of Oregon.").

252. Fairman, supra note 1 , at 32 n.58.

253. Id. at 89 . 
show that subsequent opinions reaching the opposite conclusion repudiated rather than expressed the intent of the Fourteenth Amendment's framers.

The Fourteenth Amendment was declared ratified on July 28, $1868 .{ }^{254}$ Nearly two years passed before a federal circuit court interpreted the Fourteenth Amendment for the first time. In the Slaughter-House Cases, ${ }^{255}$ decided on June 10,1870, the court concluded that the Fourteenth Amendment guaranteed not only equality of privileges or immunities, but also "that the privileges and immunities of all citizens shall be absolutely unabridged, unimpaired."256 In particular, Justice Bradley, in his capacity as Circuit Justice, concluded that the privileges of the Fourteenth Amendment included the right to pursue a lawful occupation without interference by "odious monopolies."257 The Court considered whether the law granting the monopoly conflicted with a "fundamental privilege" or was a permissible police regulation. It held that police regulations "cannot [interfere with liberty of conscience, nor with the entire equality of all creeds and religions before the law. Nor can they] ... interfere with the fundamental privileges and immunities of American citizens."258 Justice Bradley thereby articulated a theory of the Fourteenth Amendment consistent with Bingham's own: the new Amendment enforced the Bill of Rights against the states through the Privileges or Immunities Clause.

On March 12, 1871, Justice Bradley reiterated this position in a letter to Circuit Judge and future Supreme Court Justice, William Woods. Judge Woods had written to Justice Bradley for advice in deciding United States v. Hall, ${ }^{259}$ the second federal case to interpret the Fourteenth Amendment. Justice Bradley replied that fundamental rights such as speech and assembly were privileges or immunities of national citizenship under the Fourteenth Amendment. ${ }^{260}$ Judge Woods adopted Bradley's interpretation.

Judge Woods stated that, "Before the fourteenth amendment, congress could not impair [the rights contained in the first eight amendments], but the states might. Since the fourteenth amendment, the bulwarks about these rights

254. 15 Stat. 708-11 (1868).

255. Live-Stock Dealers' \& Butchers' Ass'n v. Crescent City Live-Stock Landing \& Slaughter-House Co., 15 F. Cas. 649 (C.C.D. La. 1870) (No. 8,408) (opinion of Bradley and Woods, JJ.). Fairman discussed this case, but did not acknowledge that it supported Bingham's theory of the Fourteenth Amendment. FAIRMAN, RECONSTRUCTION I, supra note 5, at 1331-35, 1362-63. Fairman never labeled the views of Justice Bradley or Judge Woods "peculiar" or "singular" even though they were the same as those articulated by John Bingham.

256. $15 \mathrm{~F}$. Cas. at 652 .

257. Id.

258. Id. at 653 (bracketed portion, citing 3 Chi. Legal News 17, in original). Judge Woods reported his published opinions in volumes known as Woods' Cases but omitted the bracketed language from that report. FAIRMAN, RECONSTRUCTION I, supra note 5, at $1333 \mathrm{n} .98$.

259. 26 F. Cas. 79 (S.D. Ala. 1871) (No. 15,282). For an account of the correspondence, see Bell v. Maryland, 378 U.S. 226, 310 n.31 (1964) (Goldberg, J., concurring); John P. Roche, Civil Liberty in the Age of Enterprise, 31 U. CHI. L. REv. 103, 108-09 (1963).

260. Roche, supra note 259 , at 109 (citing letter from Bradley to Woods (draft), Washington, D.C., March 12, 1871). 
have been strengthened, and now the states are positively inhibited from impairing or abridging them ...."261 The court specifically stated that "the right of freedom of speech, and the other rights enumerated in the first eight articles of amendment to the constitution of the United States, are the privileges and immunities of citizens of the United States . . . secured by the constitution."262

Two of the first federal prosecutions in 1871 under the Enforcement Act of $1870^{263}$ provide support for the view that the Fourteenth Amendment applied the Bill of Rights to the states. At issue was whether the Second Amendment's right to bear arms in one's home could be enforced against private individuals. The local U.S. Attorney, the Attorney General of the United States, and the grand jury returning the indictments thought they could.

As Robert Kaczorowski noted, even defense counsel, former Attorney General Henry Stanberry and Fourteenth Amendment opponent Senator Reverdy Johnson, agreed that the privileges and immunities protected by the Fourteenth Amendment included the right to keep and bear arms. ${ }^{264}$ They simply argued that those protections applied only to state actors and did not allow the federal government to take action against private parties. This defense is consistent with John Bingham's position.

A year later, the Supreme Court reversed the lower court opinion in the Slaughter-House Cases by a five to four vote. ${ }^{265}$ The Slaughter-House plaintiffs submitted portions of Bingham's congressional speeches, along with

261. $26 \mathrm{~F}$. Cas. at 81 (emphasis added).

262. Id. at 82 (emphasis added); 26 F. Cas. 1147 (S.D. Ala. 1871) (No. 15,712). The same court may have reached a like result in United States $v$. Mall decided the same year. Mall is reported only in summary form and a striking similarity exists between the facts and holdings in Hall and Mall. Fairman concluded that these are the same case with a misspelling of "Hall" as "Mall." Others have treated these cases as two distinct cases. E.g., Screws v. United States, 325 U.S. 91, 125 n.22 (1945); HYMAN \& WIECEK, supra note 102, at 436 n.90; KACZOROWSKi, THE POLITICS OF INTERPRETATION, supra note 136, at 23 n.25; Michael Collins, "Economics Rights," Implied Constitutional Actions, and the Scope of Section 1983, 77 GEO. L.J. 1493,1558 n.323 (1989).

263. 16 Stat. 140 (1870). KACZOROWSKI, THE POLITICS OF INTERPRETATION, supra note 136, at 122-32. These cases were United States v. Avery, 80 U.S. (13 Wall.) 251 (1871) (no jurisdiction), and United States v. Mitchell, 26 F. Cas. 1283 (C.C.D.S.C. 1871) (No. 15,790) (conspiracy to deprive right to vote).

264. KACZOROWSKI, THE POLITICS OF INTERPRETATION, supra note 136, at 129.

265. 83 U.S. (16 Wall.) 36 (1872). Justice Miller's distinction between the rights of state citizens and federal citizens is based upon the Citizenship Clause. However, the Citizenship Clause was not part of the original Amendment as proposed by Bingham, the Joint Committee, or the House. It was added by the Senate. FAIRMAN, RECONSTRUCTION I, supra note 5, at 1296. Eric Foner suggests that anyone who read the congressional debates would have "seriously doubted" the citizenship distinction articulated by Miller. FONER, supra note 138 , at 530 . In determining that there was a difference between the rights of a person as a citizen of a state and of that same person as a citizen of the United States, Justice Miller also alluded to Article IV, Section 2: "[T]he Fourteenth Amendment] speaks only of privileges and immunities of citizens of the United States, and does not speak of those of citizens of the several states." 83 U.S. at 74.

In paraphrasing Article IV, Section 2, Justice Miller converted the reference from privileges and immunities "of citizens in the several states" to "of citizens of the several states." He thus committed the enror of misreading Article IV, Section 2 in the way against which Bingham had warned in 1859. See supra note 67 and accompanying text. If one reads Article IV, Section 2 as Bingham read it, much of the textual argument upon which Justice Miller based his opinion cannot stand. 
those of other members of Congress, in their brief to the Court. ${ }^{266}$ The Court, however, did not refer to the debates on the Amendment or the ratification process. Instead, it relied on its own view of the purpose of the Amendment. ${ }^{267}$ The Court held that the right to pursue a lawful occupation without restraint by a state-granted monopoly was not a privilege or immunity of national citizenship. Still, the precise question of whether the Privileges or Immunities Clause incorporated the Bill of Rights was not before the Court and remained unclear. ${ }^{268}$ At least two senators, though, who voted for the Fourteenth Amendment rejected Justice Miller's interpretation. ${ }^{269}$

Four years after the Slaughter-House Cases, the Supreme Court specifically rejected the interpretation of the Fourteenth Amendment initially articulated by the lower federal courts. In United States v. Cruikshank, ${ }^{270}$ the Court, in an opinion by Justice Waite, held that the Fourteenth Amendment did not apply the Bill of Rights to the states. ${ }^{271}$ This was a repudiation of original intent rather than an attempt to apply it.

Indeed, many contemporary observers of the Court's decisions agreed with this assessment. ${ }^{272}$ In 1876, Senator Oliver Morton suggested that the Supreme Court had distorted the intent of the Fourteenth Amendment: "The fourteenth and fifteenth amendments which we supposed broad, ample, and specific, have, I fear, been very much impaired by construction, and one of

266. See 6 LANDMARK BRIEFS AND ARGUMENTS, 695, 696, 708-09, 712, 713-14 (Philip B. Kurland \& Gerhald Casper eds., 1975).

267. 83 U.S. (16 Wall.) at 68.

268. Historians continue to disagree about whether Justice Miller's opinion contemplated the application of the Bill of Rights to the States. Compare DONALD G. NIEMAN, PROMISES TO KEEP: AFRICAN AMERICANS AND THE CONSTTTUTIONAL ORDER, 1776 TO THE PRESENT 94 (1991) (Bill of Rights not applied to states) with 1 ALFRED H. KELlY ET. AL., THE AMERICAN CONSTITUTION, ITS ORIGINS AND DEVELOPMENT, Volume II 356 (7th ed. 1991) (Bill of Rights did apply); see also JOHN H. ELY, DEMOCRACY AND DISTRUST 196 n.59 (1980) (noting "at least the possibility that all nine justices" felt the post-Civil War constitutional changes made all the Bill of Rights guarantees applicable to the states). See generally Robert C. Palmer, The Parameters of Constitutional Reconstruction: Slaughter-House, Cruikshank, and the Fourteenth Amendment, 1984 U. ILL. L. REv. 739, 739, n.2.

269. George F. Edmunds indicated that Justice Miller's decision was "radically" different from "the intent of the Framers and the construction of the language used by them." PALUDAN, supra note 213, at 236 (citing 2 Charles WARREN, THE SUPREME COURT IN UNITED STATES HISTORY, 1836-1918, at 541 (1928)). Senator Timothy Howe compared Justice Miller's opinion to Dred Scott v. Sandford, 60 U.S. (19 How.) 393 (1857), and proclaimed that the American people would say that "it was not law and could not be law." Howard N. MEYeR, THE AMENDMENT THAT REFUSED To DiE 77 (rev. ed. 1978).

270. 92 U.S. (2 Otto) 542 (1876).

271. Waite's political background helps explain his opinion in Cruikshank. While he argued against slavery, supported the Union war effort, and endorsed Lincoln's Emancipation Proclamation, there is no indication he actively supported the passage of the Fourteenth Amendment. See C. PETER MAGRATr, MoRris R. WAIte: THE TRIUMPH OF Character (1963); BRUCE R. TRIMble, ChiEF JUSTICE Waite: DEFENDER OF THE PUBLIC INTEREST (1938). In 1862 Waite split the Republican (Union) congressional ticket by running as a conservative "Independent Republican" candidate against a two-term incumbent abolitionist and "regular" Republican nominee, James Ashley. REPUBLICAN PARTY OF OHIO, supra note 106, at 151. Ashley defeated Waite and his Democratic opponent with the help of John Bingham, who personally canvassed the Toledo district on Ashley's behalf. GRACE J. CLARKE, GEORGE W. JULIAN 247 (1923).

272. William M. Wiecex, The Guarantee Clause of the U.S. Constitution 164 (1972). 
them in some respects almost destroyed by construction."273 Similarly, in 1886 former Congressman and U.S. Senator James Blaine lamented that as a result of Supreme Court decisions:

[T]he Fourteenth Amendment has been deprived in part of the power which Congress no doubt intended to impart to it....

Undoubtedly a large proportion of the members of the Congress, while following the lead of those who constructed the Fourteenth Amendment, sincerely believed that it possessed a far greater scope than judicial inquiry and decision have left to it. ${ }^{274}$

At the Supreme Court Memorial Service for Chief Justice Waite in 1888, Ohio Congressman Samuel Shellabarger noted that Justice Waite's decision in United States v. Cruikshank $k^{275}$ contravened the intent of the framers of the Fourteenth Amendment: ${ }^{276}$ "[M]any of the framers of these Amendments received information regarding their intentions which was new, and was not calculated to allay the apprehensions with which they saw Chief Justice Waite go upon the bench."277 Shellabarger said that historians would later praise Waite primarily because "the lapse of years has matured men's views and cooled their feelings regarding the results of the late war."278 Like many others, Congressman Shellabarger was content with the Court's failure to enforce the "original" intent.

Three years later, Justice Brewer noted that "many of those who wrought into the Constitution the Fourteenth Amendment believed that they were placing therein a national guarantee against future State invasion of private rights, but judicial decisions have shorn it of strength, and left it nothing but a figure of speech."279

Bruce R. Trimble, a biographer of Justice Waite, later noted " $[t]$ he radical plan to protect the Negro by subjection of the states was thus 'demolished' by Waite and his associates .... Instead of getting a John Marshall [the Senators] had more nearly obtained a Roger B. Taney."280 According to Trimble,

273. 4 CONG. REC. 5585 (1876).

274. 2 JAMES G. BLAINE, TWENTY YEARS OF CONGRESS 419 (1886) (emphasis added).

275. 92 U.S. 542 (1876).

276. Appendix, In Memoriam, Morrison Remick Waite, LL.D., 126 U.S. 585 (1888).

277. Id. at 600 .

278. Id. at 600-01. So too, Hampton Carson, in his history of the Supreme Court, wrote:

But now, after the lapse of years, when the temper and spirit in which the text of the Amendments was penned have cooled, and the views of men have matured, it is seen on a survey of all the decisions considered as a body, that the value of the Court as the great conservative department of the government was never greater than then.

2 HAMPTON L. CARSON, HISTORY OF THE SUPREME COURT 485-86 (1891). Waite was also cited with approval in WARREN, supra note 269, at 616-17.

279. Hon. D.J. Brewer, Protection of Private Property from Public ATTACK, AN ADdRess DElivered Before the GRADUATING ClASSES AT THE SIXTY-SEVENTH ANNIVERSARY OF YALE LAW SCHOOL 22 (June 23, 1891).

280. TRIMBLE, supra note 271 , at 167 . Though one may read this statement more expansively, Trimble undoubtedly meant to imply only that like Taney, and unlike Marshall, Waite read national powers 
Cruikshank and the Slaughter-House Cases "marked the overthrow of the congressional plan of reconstruction within seven years after the adoption of the Fourteenth Amendment."281

Justice Moody noted that "[u]ndoubtedly, [the Slaughter-House Cases] gave much less effect to the Fourteenth Amendment than some of the public men active in framing it intended, and disappointed many others. ${ }^{2282}$ In 1926, Charles Warren, who approved of the Supreme Court's retreat from enforcing the Thirteenth and Fourteenth Amendments, ${ }^{283}$ noted that Justice Miller's opinion in the Slaughter-House Cases was "a tremendous shock and disappointment" to "the radical Reconstructionists," because "their intent in framing the language of the Amendment was directly contrary to the narrow construction now placed upon it by the Court."284

Warren stated "the course of the decisions of the Court had been, with very little variation, to controvert the purpose of the Amendment, to belittle its effect, to magnify the police power and to give it an excessively wide range. ${ }^{\text {,285 }}$ Indeed, it appears that works approving the Court's restrictive interpretation of the Fourteenth Amendment before 1949 admitted, at least implicitly, that such decisions were contrary to the original intent of the framers of the Amendment. ${ }^{286}$ Fairman appears to have been the first scholar to argue that the holdings in these cases and the intent of the framers were, in fact, consistent.

To do so, Fairman had to reconcile the apparent inconsistency among Justice Bradley's various writings. In the circuit opinion in the SlaughterHouse Cases, his letter to Judge Woods in the Hall case, and his dissent to the Supreme Court's decision in the Slaughter-House Cases, Bradley supported the

narrowly.

281. Id. at 172 .

282. Twining v. New Jersey, 211 U.S. 78,96 (1908).

283. Warren, though unwilling to pronounce the decisions of the Supreme Court correct, was willing to characterize them as "most fortunate." WARREN, supra note 269, at 608. This was so, in his view, because "[ $t]$ hey largely eliminated from National politics the negro question which had so long embittered Congressional debates; they relegated the burden and the duty of protecting the negro to the States, to whom they properly belonged; and they served to restore confidence in the National Court in the Southern States." Id.

When using the terms "the Southem States" Warren obviously referred to white supremacists and did not include millions of African Americans and white Republicans who had an equal claim to be called Southerners. Cf. Richard L. Aynes, Correspondence, 1 GA. J. Soc. LEGAL HIST. 499-501 (1991) (making same criticism about Prof. Forrest McDonald).

284. WARREN, supra note 269, at 539; see also BURGESS, supra note 204, at 228 (Slaughter-House Cases were contrary to intent of Framers and "entirely erroneous").

285. WARREN, supra note 269, at 567 (footnote omitted).

286. See, e.g., Charles W. Collins, THe Fourteenth AMEndment and the States 15 (1912). Collins, who felt little sympathy for the Fourteenth Amendment framers, concluded that the "majority of the United States Supreme Court in interpreting [the Fourteenth] amendment followed, in effect, the reasoning of the Democratic opposition, and refused to give effect to the ideas of the Radical Republicans." Id. at 15. D.O. McGovney, Privileges or Immunities Clause-Fourteenth Amendment, 4 IOWA L. BULL. 219, 219 (1918) (Supreme Court interpretation renders Privileges and Immunities Clause a narrower form of Article IV, Section 2 and "completely disappointed the avowed purposes of some of its framers"). 
view that the Fourteenth Amendment was designed to enforce the Bill of Rights against the states. Yet, Justice Bradley joined the majority in Cruikshank, apparently abandoning his earlier views and finding the Bill of Rights was not enforceable against the states through the Fourteenth Amendment.

Fairman attempted to explain this inconsistency by relying upon Bradley's statement that his changed views resulted from a continuing search for truth; ${ }^{287}$ less admiring readers viewed this change as evidence that Bradley followed the "drift" of the nation away from the commitment to enforce the Fourteenth Amendment in the face of the racial violence of the 1870's. ${ }^{288}$

Ruth Whiteside found evidence of the erosion of the guarantees of the Fourteenth Amendment to be "increasingly evident by 1873."289 According to Whiteside, by 1874 , Bradley had "begun to mirror the national mood."290 Whiteside found "no single explanation for Bradley's increasing reticence," but thought that "[t]he key lay in the nature of Bradley's commitment to the Union." "Whiteside found that Bradley gave a higher priority to "national reconciliation" among whites than to the rights of African Americans. ${ }^{292}$

Justice Bradley "gradually began to back away from his early commitments to civil rights guarantees." ${ }^{293}$ Regarding Bradley's 1883 opinion in the Civil Rights Cases, ${ }^{294}$ Whiteside concluded, in words equally applicable to his action in joining the Cruikshank majority, that "Bradley . . . spoke to the moment. His was a period piece."295

Bradley's change of heart reflected a broader social change, and not a discovery of the true intent of the framers of the Fourteenth Amendment. He never identified new debates, acknowledged errors of logic, nor discussed intervening cases that could serve as a principled basis for his change of opinion.

The Supreme Court's decisions in the Slaughter-House Cases and Cruikshank reflected the changed political climate and the retreat from Reconstruction idealism. But it was Hall and the lower court decision in the Slaughter-House Cases which best illustrate the judiciary's initial view of the true purpose of the Fourteenth Amendment. And that purpose was the one

287. FAIRMAN, RECONSTRUCTION I, supra note 5, at 1379 n.211.

288. See, e.g., HyMAN, A MORE PERFECT UnION, supra note 190, at 415-16 ("Americans did not welcome actually doing what their constitutional law ... said they should do."), 524 (noting that by 1870 . the nation "wanted stability and peace, not innovation").

289. Ruth Whiteside, Justice Joseph Bradley and the Reconstruction Amendments 182 (1981) (unpublished Ph.D. thesis, Rice University).

290. Id. at 201.

291. Id. at 230 .

292. Whiteside, supra note 289 , at 230 . Chief Judge Waite held sentiments similar to those of Bradley. MAGRATH, supra note 271, at 153. Cf. DERRICK A. BELL, JR., RACE, RACISM, AND AMERICAN LAW 29-30 (1980) (discussing "principle of involuntary sacrifice").

293. Whiteside, supra note 289 , at 190.

294. 109 U.S. 3 (1883).

295. Whiteside, supra note 289 , at 283. 
John Bingham had repeatedly espoused: to enforce the Bill of Rights against the states.

\section{CONCLUSION}

Fairman's analysis has caused many scholars and jurists to discount John Bingham's view of the Fourteenth Amendment. But a fair examination of the evidence reveals that Bingham held a cogent theory and clearly expressed his intent that the Privileges or Immunities Clause of the Fourteenth Amendment include the Bill of Rights.

Although Bingham had his critics, his colleagues in the House of Representatives and the leaders of his party respected him and frequently commended his reasoning ability. Moreover, Bingham's view that the Privileges or Immunities Clause of the Fourteenth Amendment applied the Bill of Rights to the states was not "singular." Many of his contemporaries shared this view, including three highly-regarded legal treatise writers. The first federal courts to apply the Fourteenth Amendment decided cases consistently with Bingham's position. In fact, as Michael Kent Curtis found, no contemporary source explicitly denied the contention of Bingham and his allies that the Fourteenth Amendment would enforce the Bill of Rights against the states. ${ }^{296}$ Immediately after Senator Howard's speech in the Senate stating that the Bill of Rights constituted a major portion of Fourteenth Amendment privileges and immunities, the Chicago Tribune reported that the caucus of Union Republican Senators agreed to limit debate on the Fourteenth Amendment. This action was taken because the Amendment had "already [been] thoroughly discussed and understood." ${ }^{297}$ Likewise, Governor Reuben E. Fenton of New York urged speedy ratification of the Amendment insisting that its provisions "are understood, appreciated and approved."298

Recognition of Bingham's constitutional theory as providing the correct reading of the Privileges or Immunities Clause of the Fourteenth Amendment leads to several important changes in the current constitutional landscape. First, this recognition suggests that in an appropriate case, the Supreme Court should either hold that the Slaughter-House Cases did not nullify the Privileges or Immunities Clause or, if it did, should overrule the decision. As a result, the protections of the portions of the Bill of Rights not yet incorporated under the Due Process Clause ${ }^{299}$ should be enforced against the states. The Court

296. CuRTIS, supra note 24, at 91 ("not a single senator or congressman, contradicted them").

297. Status of the Reconstruction Report, CHI. TRIB., June 1, 1866, at 2.

298. JOSEPH JAMES, THE RATTFICATION OF THE FOURTEENTH AMENDMENT 160 (1984).

299. These provisions are the Second Amendment, the Third Amendment, Fifth Amendment grand jury requirement, the Seventh Amendment, and the Eighth Amendment excessive fines and bail clause. Wermiel, supra note 24, at 129. As a result, the entire Bill of Rights would apply to citizens through the Privileges and Immunities Clause, but not to aliens. John Ely suggested that "the reference to citizens may define the class of rights rather than limit the class of beneficiaries." ELY, supra note 268, at 25 . If so, he 
should also overrule decisions which have given an amendment one meaning in the federal system and another when applied to the states. ${ }^{300}$

Finally, John Bingham, the 39th Congress, the ratifying legislatures, and antislavery theorists never suggested that the privileges or immunities of U.S. citizens were confined to the rights recognized in the first eight amendments. Rather, they viewed the Bill of Rights as defining some of these privileges and immunities and anticipated the enforcement of additional privileges or immunities, such as the privilege of protection against the states through the writ of habeas corpus. ${ }^{301}$

Discovering the identity of these "other" protections, and how they can be defined and protected, is a worthy challenge. But it is a challenge which cannot begin properly without an adequate and correct reading of the ideas of John Bingham concerning the Fourteenth Amendment.

argues the rights protected by the Privilege or Immunities Clause would extend to aliens and be more consistent with the "purpose" of the Amendment. This argument regarding the "purpose" of the Amendment, however, is not supported by the congressional debates on the Amendment.

300. See Apodaca v. Oregon, 406 U.S. 404 (1972) (no Sixth Amendment requirement of unanimous jury for felony conviction in state court, unlike federal court); Johnson v. Louisiana, 406 U.S. 356 (1972) (same conclusion under Due Process and Equal Protection analysis).

301. Amar, supra note 25 , at 1228. 